\title{
16-Dil bilimsel açıdan lakaplar: Kilis yöresi örneği
}

\section{Gülșah PARLAK KALKAN ${ }^{1}$}

APA: Parlak Kalkan, G. (2020). Dil bilimsel açıdan lakaplar: Kilis yöresi örneği. RumeliDE Dil ve Edebiyat Araştırmaları Dergisi, (Ö8), 199-223. DOI: 10.29000/rumelide.824546.

\section{$\ddot{\mathbf{O z}}$}

Dil incelemelerinin önemli bir alanını oluşturan ad bilim, aynı zamanda dil-kültür ilişkisini de incelemesi bakımından disiplinler arası bir nitelik kazanmış ve antropoloji, sosloyoloji, folklor gibi birçok bilim dalı ile ortak bir çalışma sahası yakalamıştır. Ad bilim adı altında yapılan incelemeler, oldukça geniş bir literatürü kapsadığı için zamanla alt dallara ayrılmış ve kişi adları, hayvan adları, su adları, coğrafya adları gibi daha sayılabilecek pek çok araştırma alanını malzeme sahasına dahil etmiştir. Gerek ülkemizde gerekse diğer dünya ülkelerinde ad bilimin popüler birçok alanında sayısız çalışma yapılmıştır. Hatta Almanya gibi bazı Avrupa ülkelerinde ve Rusya'da özellikle yer adları ile ilgili çok ciddi bir literatür ve çalışma disiplini oluşmuştur. Türkiye’de de ad bilimle ilgili yerel ya da bölgesel düzeyde yapılmış pek çok araştırmanın varlığı söz konusudur. Ad bilimin, en az zikredilen alanları kadar önem gerektiren bir diğer çalışma alanı ise lakaplardır. Kişinin dolayısıyla mensubu olduğu toplumun özellikle sosyal yapısının ve aynı zamanda mizah yönünün anlaşlabilmesi için bu lakapların değişik yaklaşımlarla değerlendirilmesi gerekir. Ülkemizde lakaplarla ilgili bugüne kadar yapılmış kıymetli pek çok çalışma mevcutken bu çalışmaların büyük bir kısmında şeriye sicillerindeki lakaplar araştırılmıştır. Ancak toplumun konuyla ilgili bugünkü durumunu tespit eden çalışmalara da daha fazla eğilmek gerekmektedir. Söz konusu çalışma için nitel araştırma yöntemlerinden örnek durum çalışması tekniği ile Kilis merkeze bağlı ve özellikle yerli halkın yaşadığı mahallelerden lakaplar derlenmiş ve ulaşılan veriler kategorisel içerik analizi ile tasniflenmiştir. Böylece Kilis’teki lakaplar ve lakap verme ölçütleri belirlenerek yörede bu geleneğin genel eğilimleri tespit edilmeye çalışılmıştır. Bununla birlikte veriler, dil malzemesi açısından da ayrıca değerlendirilmiştir.

Anahtar kelimeler: Ad, ad bilim, lakap, Kilis, kültür

\section{Nicknames in terms of linguistics: the sample of Kilis province}

\begin{abstract}
Onomatology, which constitutes a considerable part of linguistics, has a interdisciplinary characteristic because of its studies on language - culture relation. Thus it has a common field of study with anthropology, sociology and folklore. Because of the fact that onomatology has a large variety of literature, sub-branches have in time been formed such as anthroponomy, animal names, zone names, toponomy etc. Both in Turkiya and in many other countries of the world, many studies in numerous fields of onomatology have been carried out. Another significant field of study of onomatology is nicknames. Those kinds of nicknames are supposed to be well evaluated in order to understand the interested person, social structure and society's sense of humor. There are many valuable studies about nicknames in our country and in many of them nicknames in Şeriye Records
\end{abstract}

Dr. Öğr. Üyesi, Kilis 7 Aralık Üniversitesi, Muallim Rıfat Eğitim Fakültesi, Türkçe ve Sosyal Bilimler Bölümü, Türkçe Eğitimi ABD (Kilis, Türkiye), gulsah.parlak@hotmail.com, ORCID ID: oooo 000309869768 [Makale kayıt tarihi: 11.09.2020-kabul tarihi: 20.11.2020; DOI: 10.29000/rumelide.824546] 


\begin{abstract}
were studied. However, new studies, which determine current situation of society, should be carried out. The study in question has been carried out with the case technique which is one of qualitative research method. Nicknames have been collected from Kilis centre especially from neighborhoods in which native citizens live. Data collected have been classified with categorical content analysis method. In this way, nicknames and criteria of giving nicknames have been determined and tried to determine general trend of this tradition. In addition, collected data have been extra evaluated in terms of language material.
\end{abstract}

Keywords: Name, onomatology, nickname, Kilis, culture

\title{
Giriş
}

Ad bilim, başka bir ifadeyle onomastik, çevrede somut bir şekilde görülebilen ya da zihinle algılanabilen her şeyin adını, hem gramatikal açıdan hem de dil-düşünce, kültür ilişkisi açısından inceleyen bilim dalıdır. Ad bilimin çalışma sahası oldukça geniş ve çok çeşitli olduğu için zamanla içinde alt dallar oluşmuştur. Bu alt dallardan biri olan kişi adları bilimi (antroponomi); özel adları, soyadlarını veya lakap, mahlas gibi kişiye izafe edilen her türlü adı değişik boyutlarıyla değerlendirmektedir.

Adlar ile ilgili yapılmış ve yapılacak olan her çalışmanın kıymetini Dede Korkut, Oğuz Kağan Destanı gibi Türk kültür tarihi açısından büyük önem arz eden eserlerde, ad verme ve ad almanın belli kuralları olan bir gelenek ışığında gerçekleştirilmesi ile izah etmek mümkündür. Konuyla ilgili kaynaklardan edinilen bilgilere göre Türkler, en eski dönemlerden bu yana adın kutsal olduğuna inanmakta ve hemen her Türk coğrafyasında adlandırmanın bireyin kimliğini, varlığını somutlaştıran basit bir olgudan çıkıp dev bir folklor olayı hâline dönüştüğü görülmektedir. Bugün, Altay Türklerinde, Kırgizlarda, Kazaklarda olduğu gibi Anadolu topraklarında da bebek, dünyaya geldikten birkaç gün/birkaç hafta/birkaç ay sonra türlü ritüeller ve merasimler eşliğinde ad almaktadır. Kişiye iradesi dışında verilen bu adlar, aile büyüklerinin zihninde kodlanmış toplumsal normların yansıması olabileceği gibi toplumdan bağımsız, bireysel zevk, beğeni ve tercihlerin de yansıması olabilmektedir. Dolayısıyla başlangıçta dil bilimin malzemesi olan adlar zamanla halk bilimin, sosyolojinin ve hatta dil-düşünce ilişkisi bağlamında psikolojinin de çalışma sahası olmuştur.

Ad bilim çevresinde üzerinde ehemmiyetle durulması gereken bir mevzu olan lakap, Arapça kökenli bir kelime olup sözlüklerde "bir kimseye ya da bir aileye kendi adından ayr olarak sonradan takulan ad" (Türkçe Sözlük, 2005), "bir kimseye kendi asıl adından başka takılan ad" (Devellioğlu, 1995:541), "bir kimsenin temsil ettiği makam veya göreviyle ilgili olarak anıldiğı ad ya da sıfat, hükümdarlık alameti” (İslamansiklopedisi.org.tr, erişim tarihi: 19.04.2020) şeklinde tanımlanmaktadır.

Diğer pek çok kültürde olduğu gibi Türk kültüründe de lakap geleneği oldukça önemlidir. Türklerde kişilere lakap verilmesi İslamiyet öncesinde de sonrasında da uygulanan bir gelenektir. Dede Korkut'ta kişilerin gösterdiği kahramanlıklara bağlı adlarına çeşitli sıfatlar eklenir. Karahanlılar döneminde kişilerin adlarından önce ya da sonra "kara" lakabını kullandıkları görülür. Hatta bu lakap verme geleneği o kadar geniş bir alana yayılmıştır ki insan dışında canlılara ve cansızlara da lakap verildiği Hz. Peygamberin devesine Kasva, miraca yükseldiği bineğine Burak; Hz. Ali’nin atına düldül, kılıcına ise zülfikar adlarının verilmesi örneklerinde görülmektedir (Sevinç, 2019:312). 
Osmanlılarda da ailelerin sülale veya soyadı olarak mutlaka bir lakaplarının olması oldukça yaygın bir durumdur. Bu toplumda kullanılan lakaplar, kişinin ait olduğu sosyal sınıfi, memleketi, ilmî durumu gibi özelliklerini belirtmekle birlikte 16. yüzyılın sonlarına kadar sıklıkla devam etmiş; bu yüzyıldan sonra azalmaya başlamış ve Cumhuriyet'in ilk yıllarında Soyadı Kanunu'nun da kabulüyle giderek kaybolmuştur (Şakar, 2006:169).

21 Haziran 1934 tarihinde Medeni Kanun'un ve Dil İnkılabı'nın parçası olarak kabul gören Soyadı Kanunu'na değin Türkiye'de kişiler, baba soyadı yahut da lakaplarla tanınmakta idi. Osmanlı İmparatorluğu'nun çatısı altındaki halk, vatandaş değil, tebaa statüsünde olduğu için çağdaş düzeydeki bireysel hak ve özgürlükler oldukça geç olgunlaşmıştır. Bu maksatla atılan adımlar arasında yer alan Soyadı Kanunu ile insanları birbirinden ayırt etme, lakaplarla değil soyadları ile sağlanacaktır. Yine halkın önceden kullandığı lakap ve unvanları soyadı olarak almalarına engel olmak için de 29 Kasım 1934'te "efendi, bey, paşa" gibi lakap ve unvanların kaldırılmasına dair bir kanun daha çıkarılmıştır (Doğaner, 2007:250-251).

Ancak herhangi bir sebeple birbirini tanımayan insanlar, bir araya geldiklerinde birbirlerine sordukları, soracakları ilk şey "Nerelisin? Kimlerdensin?” soruları örneğinde olduğu gibi akrabalık bağlarının kuvvetli olduğu Türk toplumunda, kanun önünde lakap ve unvanlar kaldırılmış olsa da halk arasında ailelerin soyadlarıyla birlikte aile lakaplarıyla da tanınır olmaları devam etmiştir (Tan, 2016:103).

Günümüzde halk nezdinde de yaygınlı oranı gittikçe azalmış olan lakapların toplumsal boyutunun aksine özellikle Anadolu'nun küçük yerleşim birimlerinde ve insan ilişkilerinin daha yoğun ve sıkı olduğu mahallelerde kişilerin bireysel özelliklerine bağlı olan kişisel boyutu yaygın bir şekilde devam etmektedir (Kardaş, 2018.212). Geleneksel yaşam tarzının sıkı sıkıya korunduğu buralarda çoğunlukla kişiye, şahsına bağlı dinî, etnik, fizikî özellik, ahlakî durum, memleket, gelir seviyesi, eğitim durumu gibi sebeplerle türlü yakıştırmalar yapma durumu söz konusudur (Coşar, 2003:27).

Yakıştırma, takma ad gibi değişik şekillerde de ifade edilen lakap geleneğinde, kişilere asıl adları verilirken birinci derecede etkili olan toplumsal normların varlığından söz etmek güçtür. Lakaplar verilirken ne Muhammed, Ali, Kübra gibi adlarda olduğu gibi dinin etkisi ne de Atilla, Oğuz, Osman gibi adlarda olduğu gibi millî değerlerin etkisi görülür. Elbette ki bu ölçütlerin lakap geleneğini hiçbir şekilde etkilemediğini söylemek de doğru olmayacaktır. Bu bakımdan lakap için bireyin serbest davranışının tezahür şekli de denilebilir (Kabak, 2014:4-5).

Neticede kişinin toplum nazarında öne çıan bir özelliğinin ifade bulmuş şekli olan lakapları Boyraz, çalışmasında şu örnek aracılığıyla somutlaştırmıştır: Bir gün köye, diğer köylerin birinden misafir gelir. Köy odasında sohbet devam etmekte iken köy ahalisinden birkaç kişi kendi aralarında konuşurken "ölüynen motur camiye girdi" cümlesini sarf eder. Konuşmaya kulak misafiri olan diğer köylü, buna anlam veremez ve "Bu nasıl olur?" diye sorar. Bunun üzerine odadakiler kendi aralarında gülüştükten sonra "Köyde iki kardeş var. Birine çok çalıştığı için motor, diğerine de tembel olduğu için ölü diyoruz.” derler. (Boyraz, 1998:110). Örnekten de anlaşlacağı üzere lakapların oluşum sebepleri övme, yerme ve tanıtma şeklinde izah edilebilir. Bu yönüyle lakaplar, dil bilim/ad bilim açısından önemli bir malzeme sahası olmasının yanında sosyolojik, antropolojik ve folklorik açıdan da ait olduğu toplumla iligli birçok bilgiyi kodlayan göstergeler olarak değerlendirilebilir (Aydın, 2006:28).

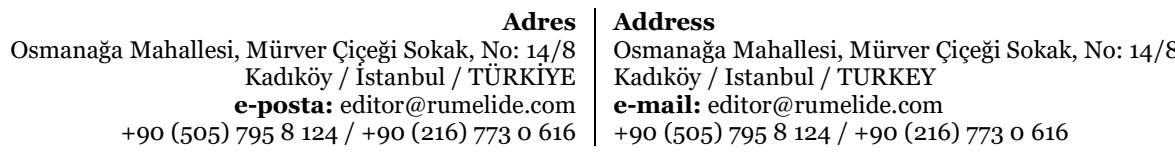


Ülkemizde lakapları, yukarıda zikredildiği gibi hem dil hem de dil-kültür ilişkisi bağlamında irdeleyen pek çok çalışma bulunmaktadır ve buna bağlı olarak konuyla ilgili ciddi bir literatür oluşmuş durumdadır. Hâl böyleyken konunun belli bir sistematiğinin oluşturulduğunu söylemek güçtür. Bunu sağlamak için Türkiye'nin her karışını içine alan daha pek çok çalışmanın yapılması büyük önem arz etmektedir. Lakaplarla ilgili alanyazın taranırken bilhassa Osmanlı arşivlerindeki ve şeriye sicillerindeki lakaplarla ilgili çalışmaların bolluğu dikkat çekmektedir:

Menekşe, Bodrum'da kullanılan lakapları sosyo-kültürel açıdan değerlendirdiği çalışmasında (Menekşe, 2017), Bodrum kasabasının 9 mahallesine ait 1845 tarihli temettuat defterini malzeme sahası olarak belirlemiştir. Lakapların anlam ya da başka açlardan kategorisel herhangi bir analizin yapılmadığı çalışmada daha çok o dönemde kullanılan lakapların betimsel olarak tespiti ile ülkenin Soyadı Kanunu'na giden süreçteki durumu ve bu durumu gerektiren sebepler belirlenmeye çalışılmıştır. Tamamı 162 sayfa olan bu defterlerde kayıtlı olan 589 hanedan 387'sinde lakap tespit edilmiştir. Verilerin yorumlanmasıyla örneğin kasabadaki 9 mahalleden birinin Rum mahallesi olduğu ve halkının da gayrimüslim olduğu yine Cezayirli, Çineli, İstanbullu, Giritli gibi lakaplardan da yakın/uzak Osmanlı şehirlerinden kasabaya yerleşmiş ahalinin varlığı gibi bilgilere ulaşılmıştır. Menekşe tarafından hazırlanan bir başka çalışmada ise (Menekşe, 2019), Başbakanlık Osmanlı arşiv kayıtlarından bugün Eskişehir'e bağlı olan Seyitgazi kasabasında XIX. yüzyıl ortalarında kullanılan kişi adları ve lakaplar, benzer diğer çalışmasındaki yöntemle tespit edilmiş ve veriler ışı̆̆ında sosyokültürel açıdan çeşitli yorumlarda bulunulmuştur. Şimşek tarafından hazırlanan Osmanlı Devleti’nde engelliler için kullanılan tabir, lakap ve sıfatların arşiv belgelerinden tespit edildiği çalışmada (Şimşek, 2018), kişiye engel durumuna göre takılan lakaplar tasniflenmiştir. Tekin ve Ceylan, Safranbolu şeriye sicillerindeki eşya, lakap ve yer adlarını kategorize tabloları oluşturarak inceledikleri çalışmalarında (Tekin ve Ceylan, 2017), bu adların mümkün olduğunca doğru okunuşunu belirleyerek kent tarihi ve sosyal hayatı ile ilgili çalışma yürütecek olanlara kaynaklık etmeyi amaçlamışlardır. Şeriye sicilleri kullanılarak hazırlanan bir başka çalışma ise XIX. yüzyılda Kıbrıs'ta kullanılan lakap ve unvanlardır (Akçam, 2015). Akçam, çalışma ile ele aldığı ă̆a, efendi, karantina kâtibi, kavas, kethüda gibi 16 adet lakap ve unvanı değişik açlardan yorumlamıştır. Lakaplarla ilgili burada bahsi geçen çalışmalar dışında da pek çok kıymetli çalışma (Akdağ, 2014; Aksu, 2001; Aktan, 1970; Kibar, 2017; Oğuz ve Oğuz, 2008; Özdemir ve Erdem 2016; Özkan, 2016; Semih, 1993; Toygar, 1979; Üçer, 1992; Yıldızkaya, 2014) bulunmaktadir.

\section{Yöntem}

Söz konusu çalışma, betimsel bir araştırma olup 2018 ve 2019 yıllarının muhtelif zamanlarında Kilis il merkezinde özellikle yerli halkın yaşadığı Zeytinli, Tekye, Çengel gibi mahallelerden kaynak kişiler aracılı̆̆ıyla 337 adet lakap derlenmiştir. Kategorisel açıdan değerlendirilen lakaplar, içerdikleri anlamlara göre: 1. Niteliksel Özelliklerle İlgili Lakaplar (Etnik, Din, Aile-Akraba-Soy, Yaşam Biçimi, Yetenek ve Beceri, Mizaç, Olumlu Tutum ve Davranış, Olumsuz Tutum ve Davranış) 2. Dış Görünüş ile İlgili Lakaplar (Fizikî Durum, Kıyafet-Ayakkabı vb. özellikler, Dış Görünüşte Bir Engel veya Kusur, Ünlü Birine Benzeme) 3. Tercih Edilen veya Edilmeyen Durumlarla İlgili Lakaplar (Yanından Ayırmadığı Bir Nesne, Sık Kullanılan Söz, Zevk, Hoşa Gitmeyen Durumlar) 4. Mesleklerle İlgili Lakaplar şeklinde dört ana başlıkta ve alt başlıklarda tasniflenmiştir.

Ayrıca anlamlarına göre lakaplar bölümünde, işaret ettiği sözlük anlamından benzetme yoluyla başka bir anlama işaret eden lakaplar açlklanırken sözlük anlamı ile örtüşen lakaplarla ilgili herhangi bir açıllama yapılmamıştır. 
Öncelikli olarak dil-kültür ilişkisi bağlamında bu şekilde değerlendirilen lakaplar, Türkçenin kullanımı ve söz varlığı açısından da değerlendirilmeye çalışılmıştır. Bu maksatla lakaplar Türkçe olup olmama durumunlarına göre tasniflenmiş; aynı zamanda lakapların anlam ve kökenleri ekler bölümündeki sözlük kısmında ayrıntılı bir şekilde izah edilmiştir. Ayrıca lakaplar yapı bakımından da basit, birleşik, türemiş olma durumlarına göre tasniflenerek yine ekler bölümünde oluşturulan tablolarda istatistiki açıdan değerlendirilmiştir.

\section{Lakapların tasnifi}

\subsection{Anlam bakımından lakaplar}

\subsubsection{Niteliksel özellikerle ilgili lakaplar}

\subsubsection{Etnik kökene bağlı lakaplar}

Arap (Hasan), Kürt (Ahmet).

\subsubsection{Din ile münasebete bağlı lakaplar}

Devriş (Hayll), Ermiş (Şükrü), Hafız (Hikmet), Mason (Ali), Uğurlu (Halil).

\subsubsection{Aile, akraba, soy ile ilgili durumlara bağlı lakaplar}

Garip (Mahmut), Halle (Mehmet), İncirkuşu (Kerem), Gazioğlu, Paşa(Cemal): Bu kişinin ataları Osmanlı paşalarından olduğu için bu lakap verilmiştir. Peltek (Kemal): Bu kişinin tüm aile bireyleri peltek olduğu için bu lakap verilmiştir. Seydo (Ali): Babasının adı Seydo olduğu için bu lakap verilmiştir. Şaşı (Ahmet): Tüm aile fertlerinin gözleri şaşı olduğu için bu lakap verilmiştir. Şiltelioğlu (Mehmet): Dedesi, ölen kişilerin giysi, yatak gibi tüm şiltelerini toplayıp aldığı için bu lakap verilmiştir. Topalfakıgil, Uzunoğlu (Mennan): Babası çok uzun boylu olduğu için bu lakap verilmiştir. Vezir (Ahmet): Dedesi, sarayda padişaha hizmette bulunduğu için bu lakap verilmiştir. Veci (Salih): Abisinin kumarbazlık, zamparalık vb. gibi kötü alışkanlıkları olduğu için bu lakap verilmiştir. Zıbar (Ali): Annesi, bu kişiye hep "Zıbar Ali." dediği için bu lakap verilmiştir.

\subsubsection{Yaşam biçimine bağlı lakaplar}

Dağdelisi (Durmuş), Evsiz (Harun), Gezgin (Halil), Varoş (Kazım), Yosma (Dilek): Bir erkeğin nikâhsız, ikinci eşi olduğu için bu lakap verilmiştir.

\subsubsection{Maddi duruma bağlı lakaplar}

Hancı (Kemal): Gelir getirisi yüksek bir oteli olduğu için bu lakap verilmiştir.

\subsubsection{Yetenek ve becerilere bağlı lakaplar}

Amud (Ali), Barak (Ali): Barak türkülerini güzel söylemesine bağlı verilmiş bir lakaptır. Beton (Cemal): Sabit durunca kimsenin bu kişiyi yerinden kıpırdatamamasına bağlı verilmiş bir lakaptır. Burgu (Necmi): Burgu denilen vidayı törpüyle yapmasına bağlı verilmiş bir lakaptır. Çalgıcı (Kör Elif), Canbaz (Mecit), Dabaz (Habip), Dama (Yusuf), Dükçü (Şakir): Hedef aldığı her şeyi vurmasına, nişancı olmasına bağlı verilmiş bir lakaptır. Erbap (Halit), Ezgin (Hasan), Fakı (Güler), Füze (Hacı):

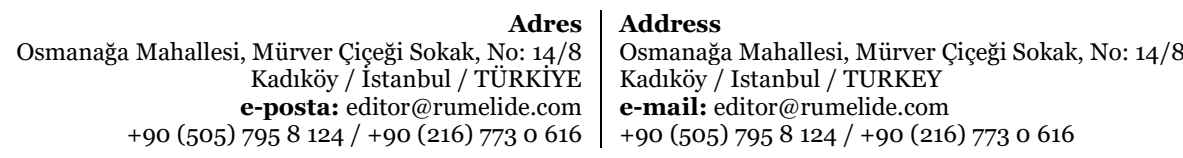


Müş̧erilerini gideceği yere çok kısa bir sürede ulaştıran şoför olmasına bağlı verilmiş bir lakaptır. Haketçi (Mehmet): Ezbere pek çok hikâye anlatmasına bağlı verilmiş bir lakaptır. Halle (Mehmet), Hapsacı (Yaşar), İncirkuşu (Kerem), Kaşmer (Murat), Maskara (Necmi), Mastika (Necla), Papaz (Duran), Radar (Mahmut), Topalfakıgil, Zambırlı (Celal).

\subsubsection{Mizaca bağlı lakaplar}

Böke (Mustafa), Canıcebindegil, Cilveli (Halil), Çepik (Zeki), Çıtkırıldım (Ömer), Dürüst (İbrahim), Düşkün (Halil), Efendi (Ağa), Fosfor (Yusuf), Gevrek (Hasan): Çok alıngan olmasına ve çabuk kırılmasına bağlı verilmiş bir lakaptır. Gelgit (Ahmet), Kız (Salih), (Nazik (Mahmut), Nedametli (Cuma), Öhlez (Hoca), Sakar (Mustafa), Şahbaz (Mustafa), Sehlek (Mehmet), Taşkala (Mustafa), Umar (Hasan), Uysal (Kenan), Vukuf (Ali), Vasat (Halil), Yollı (Mehmet), Yumuk (Akif): İçine kapanık biri olmasına bağlı verilmiş bir lakaptır.

\subsubsection{Olumlu tutum ve davranışa bağlı lakaplar}

Ayar (Ali), Baba (Reşit), Hayma (Veli), Rafık (Kerim): Dostluğunun, arkadaşlığının iyi olmasına bağlı verilmiş bir lakaptır. Vuslat (Kadir): Kendisine kötülük yapana bile iyilik yapacak kadar iyi niyetli olmasına bağlı verilmiş bir lakaptır.

\subsubsection{Olumsuz tutum davranış ve alışkanlığa bağlı lakaplar}

Arsız (Kadir), Bitirim (Celal), Beleşçi (Halil), Bedelci (Salih), Berduş (Duran), Avare (Hikmet), Arakçı (Duran), Ayyaş (Bedri), Çelet (Ali), Çakır (Ahmet), Dilbaz (Duran), Fesat (Tahir), Fosayak (Necmi), Fiskos (Naciye), Gavur (Halil), Geveze (Celal), Gözcü (Ali), Hasıt (Mahmut), Harami (Necmi), Kelek (Halil): Konuşmalarının ham olmasına bağlı olarak verilmiş bir lakaptır. Lafazan (Celal), Öküz (Ahmet), Pire (Mahmut): Herhangi bir yeri yaralandığında akan kanı emmesine bağlı verilmiş bir lakaptır. Puşt (Durmuş), Pişkin (Ali), Sülük (Mehmet), Sarhoş (Nail), Tamah (Ökkeş), Tilki (Hasan), Vampir (Ahmet): Herhangi bir yeri yaralandığında akan kanı emmesine bağlı olarak verilmiş bir lakaptır. Vahşi (Kadir): Karnını, avlayıp pişirdiği hayvanlarla doyurmasına ve hiç kimseyle konuşmamasına bağlı verilmiş bir lakaptır. Yobaz (Memik), Yangın (Leyla): Mahallenin tüm erkeklerini ayartmasına bağlı verilmiş bir lakaptır. Yalancı (Adem), Zalim (Orhan), Zampara (Necmi).

\subsubsection{Dış görünüşse bağlı lakaplar}

\subsubsection{Fiziki duruma bağlı lakaplar}

Abuosmanoğlu (Vedat): Dış görünüşünün heybetini gören herkesin "Abo" demesine bağlı verilmiş bir lakaptır. Altındiş (Mehmet), Ayrancı Pompal (Hasan), Beyaz (Tayfun): Saç, sakal, kirpik ve kaşının beyaz olmasına bağlı verilmiş bir lakaptır. Barmil (Mehmet), Behlek (Şakire), Bodur (Ali), Boynuyoğungil (Apo), Burnubüyük (Apo), Civelek (Hasan), Cücük (Hösen), Çakşır (Halil), Çapaklı (Abdi), Dabanıböyük (Hamza), Debbe (Ali): Plastik bidon kadar şişman olmasına bağlı verilmiş bir lakaptır. Esvet (Recep), Filik (Zeki), Fodul (Ali), Güleç (Kamil), Gürgen (Adem), Geviş (Duran), Hecin (Yusuf), Kambur (Hasan), Karaoğlan (Salih), Kel (İzzetgil), Lök (Hasan), Marazlı (Sadık): Vücudunun her yerinde sürekli yara olmasına bağlı olarak verilmiş bir lakaptır. Mostura (Serpil), Sarıbaş (Mustafa), Sinekli (Ali); Semiz (Mustafa), Tazı (Cemil): İnce bacaklı, küçük başlı olmasına bağlı verilmiş bir lakaptır. Tuvarlak (Zeko), Taslak (Kadir): Yüzünün yayvan, dümdüz olmasına bağlı 
verilmiş bir lakaptır. Uzun (Şükrü), Varil (Mahmut), Yavan (Veli), Siyeç (Ali): Ellerinin çalı gibi nasırlaşmış olmasına bağlı verilmiş bir lakaptır.

\subsubsection{Kıyafet ayakkabı gibi özelliklere bağlı lakaplar}

Çarpanalı (Cemil), Çamur (Şevket), Etekli (Ali), Erkek (Ayşe): Erkek kıyafetleri giymesine bağlı verilmiş bir lakaptır. Narçiçeği (Ali): Kıyafetlerinin yakasına her zaman narçiçeği takmasına bağlı verilmiş bir lakaptır. Rükuş (Şükriye), Rozet (Kamil), Taykeş (Mahmut), Ukcursuz (Mesut), Yamalıklı (Zeki).

\subsubsection{Dış görünüşteki bir engel veya kusura bağlı lakaplar}

Ağzıeğrigil, Çalgıcı Kör (Elif), Çolak (Tahir), Kambur (İsmail), Sağır (Nafi), Tekdaşşak (Mustafa), Topal (Halil), Urlu (Ahmet): Yanağında büyük bir beze olmasına bağlı verilmiş bir lakaptır.

\subsubsection{4. Ünlü birine benzemeye bağlı lakaplar}

Makaryos (Mustafa).

\subsubsection{Tercih edilen veya edilmeyen durumlara bağlı lakaplar}

\subsubsection{Yanından ayırmadığı bir nesneye bağlı lakaplar}

Aynalı (Tahir), Borazancı (Ali).

\subsubsection{Sık kullanılan sözlere bağlı lakaplar}

Çeksündür (Mahmut): Yetişmeyen her ip, tel, kumaş gibi nesneler için "Süner, süner." demesine bağlı olarak verilmiş bir lakaptır. Deve (Şükrü); Abartılı gördüğü her söylem için "Yok deve!” demesine bağlı verilmiş bir lakaptır. Dandik (Vedat): Hiçbir şeyi beğenmemesine ve her şeye "dandik" demesine bağlı verilmiş bir lakaptır. Eşşek (Sülo): Pişmanlık duyduğu her durum için "Eşşek kafam!" diye kendi kendine kızmasına bağlı verilmiş bir lakaptır. Hasta (Halil), Hoşaf (Osman): Ne yedin diye sorulduğunda hep "hoşaf" demesine bağlı verilmiş bir lakaptır, Lilik (Fero), Pissik (Abdi): Sürekli "miyav" diyerek gezmesine bağlı verilmiş bir lakaptır. Rolans (Ahmet): Her işe başlamadan önce düşünmek için "rolans" demesine bağlı verilmiş bir lakaptır. Tintin (Mustafa), Vakkas (Ökkeş): Sürekli kaz gibi vaklaması sebebiyle "vak-kaz" denilmesine bağlı verilmiş bir lakaptır. Bahtiyar (Akif), Zukkum (Mustafa): Kızdığı herkese “Zukkum ye.” demesine bağlı verilmiş bir lakaptır.

\subsubsection{Zevke bağlı lakaplar}

Alafiranga (Halil), Antika (Necmi), Depikçi (Durmuş): Sokakta yürürken her nesneye tepik atmaktan mutluluk duymasına bağlı verilmiş bir lakaptır. Gezer (Recep), Geyik (Ahmet), Gülkurusu (Ahmet): Rengârenk, her gülü kurutmasına bağlı verilmiş bir lakaptır. Lappa (Ali), Malhıta (Zeko): Mercimek çorbasını çok sevmesine bağlı verilmiş bir lakaptır. Roket (Mesut): Havaya uçan her nesneyi sevmesine bağlı verilmiş bir lakaptır. Robot (Halil), Laz (Yaşar).

\subsubsection{Hoşa gitmeyen durumlara bağlı lakaplar}

Çökelek (Abuş): “çökelek” sözünden rahatsız olmasına bağlı verilmiş bir lakaptır.

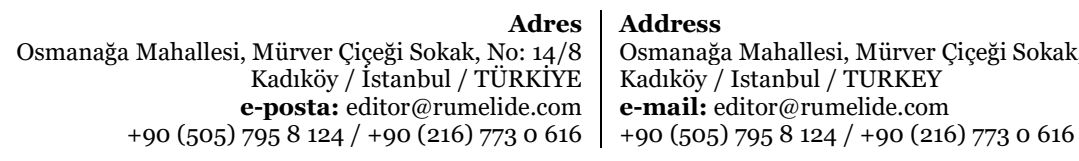




\subsubsection{Mesleklerle ilgili lakaplar}

\subsubsection{Meslek adına bağlı lakaplar}

Abbehgil, Attar (Hüseyin), Aşçığlu (Hüseyin), Ayakçı (Şakir), Badanacı (Osman), Bekçibaşı (Mahmut), Bahçeçi (Şıho), Baytar (Mustafa), Barancı (Osman), Budamcı (Halil), Basmanacı (Abdi), Bastacı (Mahmut), Çı̆̆ırtkan (Kemal), Çerçi (Hasan), Dokumacı (Ali), Çıkıkçı (Hösne), Debbă̆ (Ömer), Dellek (Ahmet), Ebe (Şerife), Fırıncı (Halil), Foto (Ahmet), İğneci (Şefo), Kalaycı (Ahmet), Kebapçı (Yaşar), Köçek (Ali), Köşker (Hasan), Nakkaş (Halil), Neyzen (Kemal), Perdeci (Hayrettin), Rakkas (Ali), Rakkase (Leyla), Uyaran (Kemal): Herhangi bir iş için (namaz, sahur) erken kalkmak isteyenleri ücret karşılığında uyandırmasına bağlı verilmiş bir lakaptır. Yıkımcı (Hasan), Yapıcı (Salih), Nalbant (Ahmet).

\subsubsection{Satılan ürüne veya üretilen malzemeye bağlı lakaplar}

Bafon (Necmi), Başakçı (Emin), Bekereci (Mehmet), Bavulcu (Ali), Darakçı (İhsan), Döşekçibacı (Ayşe), Davulcu (Bektaş), Eskimocu (Salih), Eskici (Mehmet), Frrıldak (Ali), Fennüs (Nuri), Ferik (Hasan), Fahreci (Kamil), Gazozcu (Ali), Gemici (Adil): Oyuncak gemi üretmesine bağlı olarak verilmiş bir lakaptır. Gülcü (Nedim), Gergef (Ali), Haruf (Ali), Hasırcı (Habip), Körükçü (Mustafa), Kömürcü (Arap), Kürtüncü (Mahmut), Külekçi (Ahmet), Kurşun (Ahmet), Löküsçü (Macit), Lokumcu (Osman), Loğlaz (Yaşar), Levhacı (Halil), Lastik (Duran): Her türlü plastik eşya satmasına bağlı verilmiş bir lakaptır. Mintancı (Bekir), Mantocu (Hayri), Nalıncı (Hikmet), Nergizci (Hasan), Nahırcı (İzzet), Paraşüt (Cemil): Zeytin toplamak için ağacın altına açılan ve seri bir şekilde toplanmasını sağlayan bir tür yer paraşütü yapmasına bağlı verilmiş bir lakaptır. Postçu (Kadir), Semsek (Rıza), Summak (Mustafa), Tabak (Ali), Turfanda (Hasan), Topuz (Hösen), Tuluk (Hasan), Tepirci (Ali), Yalak (Mahmut), Yüncü (Ali), Zambut (Ali), Zurnacı (Bektaş), Zulacı (Tahir): Kaçakçılık yapan kişilerin araçlarına gizli bölmeler yapmasına bağlı verilmiş bir lakaptır. Barhanacı (Ali), Bahteniz (Celal), Bağırsakçı (Durmuş), Çapıt (Abdi), Çeketçi (İbo), Çatpat (İhsan), Çörtenci (Hakkı), Darıı (Necmi), Darabacı (Mahmut), Dambıracı (Ali), Dereççi (Mahmut), Dürbekici (Sadık), Davarcı (Mustafa), Dolakçı (Nazmi), Sarraf (Hösen), Varak (Ahmet), Damızlıkçı (Yaşar).

\subsubsection{Mesleğin icra edildiği alete bağlı lakaplar}

Dibekçi (Ahmet), Loğ (Mahmut), Mızıkacı (Hasan), Mastarcı (Eyüp), Soku (Ali), Tablacı (Ali), Vapur (Ali), Zilli (Fattum), Sülükçü (Durmuş), Lök (Hasan), Lambacı (Mehmet).

\subsubsection{Herhangi bir sebeple veya bir olayla ilgili lakaplar}

Adakçı (Ali): Dileği gerçekleşen kimselerin kestiği adak kurbanından bu kişinin mutlaka haberdar olmasına ve payına düşeni almasına bağlı verilmiş bir lakaptır. Akıllı Teypçi, Alman (Hanifi): Kilis'ten Almanya'ya çalışmak üzere giden ilk kişi olmasına bağlı verilmiş bir lakaptır. Ataş (Ali): Her mahallede yerde gördüğü çeri çöpü ateşe vermesine bağlı verilmiş bir lakaptır. Azıkçı (Nail): Cebinde her zaman bir yiyecek bulundurmasına bağlı verilmiş bir lakaptır. Bahtsız (Hasan), Güve (Hayri): Sokakta bulduğu her şeyi evine götürüp kullanmadığı için de bir süre sonra böceklenmesine bağlı verilmiş bir lakaptır. Heryeri (Hayri): Her yere herkesten önce gitmesine bağlı verilmiş bir lakaptır. Eskort (Necmi): Özel günlerdeki her türlü etkinlikte devlet büyükleriyle beraber en önde bulunmasına bağlı verilmiş bir lakaptır. Asfalt (Mıstık): Asfalt yol yapıldıktan sonra bir kere bile toprak yolu kullanmamasına bağlı verilmiş bir lakaptır. Ayıboğan (Halil): Önceleri çingeneler Kilis sokaklarında

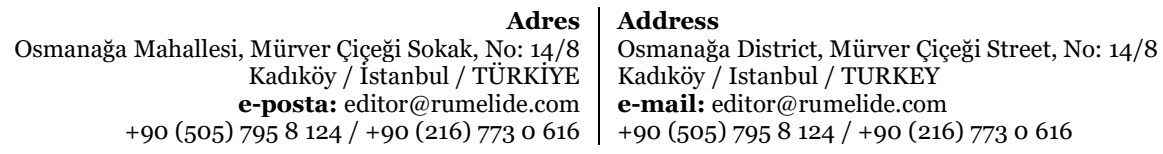


burnunda demir halka takılı ayı oynatırlarmış. Birgün bu ayılardan biri, Halil'e saldırınca o da ayıya saldırmış ve boğmuş bunun üzerine de bu lakabı almıştır. İngiliz (Mahmut), Katil (Ahmet), Kırdök (Ali), Kazan (Ali): Bir oturuşta bir kazan yemeği yemesine bağlı verilmiş bir lakaptır. Leylek (Mustafa): Çocukken anne-babasının "Seni leylekler getirdi." demelerine inanmasına bağlı verilmiş bir lakaptır. Mestan (Mahmut): Otururken hep uyuklamasına bağlı verilmiş bir lakaptır. Necis (Durmuş): Çok pis kokmasına bağlı verilmiş bir lakaptır. Pasaklı (Seval): Kendisi gibi evinin de çok kirli olmasına bağlı verilmiş bir lakaptır. Porsuk (Muzaffer): Porsuk gibi pis koku saçmasına bağlı verilmiş bir lakaptır. Rotüş (Hasan): Her türlü işin son düzeltmelerini kendisinin yapmasına bağlı verilmiş bir lakaptır. Sinek (Mehmet), Vabıs (Muharrem): Vabıs marka kamyonunun tüm tamirini kendisinin yapmasına bağlı verilmiş bir lakaptır.

\subsection{Yapı bakımından lakaplar}

\subsubsection{Basit yapılı lakaplar}

Alafıranga (Halil), Alman (Hanifi), Amud (Ali), Antika (Necmi), Arap (Hasan), Asfalt (Mıstık), Âşık (Ahmet), Ataş (Ali), Avare (Hikmet), Ayar (Ali), Ayyaş (Bedri), Baba (Reşit), Bafon (Necmi), Behlek (Şakire), Bahteniz (Celal), Bahtiyar (Akif), Barak (Ali), Barmil (Mehmet), Baytar (Mustafa), Berduş (Duran), Beton (Cemal), Beyaz (Tayfun), Bitirim (Celal), Bodur (Ali), Böke (Mustafa), Burgu (Necmi), Canbaz (Mecit), Civelek (Hasan), Cücük (Hösen), Çakır (Ahmet), Çamur (Şevket), Çapıt (Abdi), Çelet (Ali), Çepik (Zeki), Çerçi (Hasan), Çolak (Tahir), Çökelek (Abuş), Dabaz (Habip), Dama (Yusuf), Dandik (Vedat), Debbağ (Ömer), Debbe (Ali), Dellek (Ahmet), Derviş (Mayıl), Deve (Şükrü), Dürüst (İbrahim), Ebe (Şerife), Efendi (Ağa), Erbap (Halit), Eskort (Necmi), Esvet (Recep), Eşşek (Sülo), Fennüs (Nuri), Ferik (Hasan), Ferrari (Yusuf), Fesat (Tahir), Filik (Zeki), Fiskos (Naciye), Fodul (Ali), Foto (Ahmet), Füze (Hacı), Garip (Mahmut), Gavur (Halil), Geveze (Celal), Geviş (Duran), Geyik (Ahmet), Görgen (Adem), Güve (Hayri), Hafiz (Hikmet), Halle (Mehmet), Harami (Necmi), Haruf (Ali), Hasit (Mahmut), Hasta (Halil), Hayma (Veli), Hecin (Yusuf), İngiliz (Mahmut), Kambur (Hasan), Kaşmer (Murat), Katil (Ahmet), Kazan (Ali), Kel (İzzetgil), Kelek (Halil), Kız (Salih), Köçek (Ali), Köşker (Hasan), Kurşun (Ahmet), Kürt (Ahmet), Lafazan (Celal), Lastik (Duran), Laz (Yaşar), Leylek (Mustafa), Lilik (Fero), Loğ (Mahmut), Loğlaz (Yaşar), Lappa (Ali), Lök (Hasan), Makaryos (Mustafa), Malhita (Zeko), Maskara (Necmi), Mason (Ali), Mastika (Necla), Mastura (Serpil), Mestan (Mahmut), Nakkaş (Halil), Nazik (Mahmut), Necis (Durmuş), Öhlez (Hoca), Öküz (Ahmet), Papaz (Duran), Paraşüt (Cemil), Parça (Ahmet), Paskil (Hasan), Paşa (Cemal), Peltek (Kemal), Pire (Mahmut), Pissik (Abdi), Porsuk (Muzaffer), Puşt (Durmuş), Radar (Mahmut), Rafik (Kerim), Rakkas (Ali), Rakkase (Leyla), Robot (Halil), Roket (Mesut), Rolans (Ahmet), Rotuş (Hasan), Rozet (Kamil), Rüküş (Şükrüye), Sağır (Nafi), Sakar (Mustafa), Soku (Ali), Sarı (Tahsin), Sarraf (Ali), Sehlek (Mehmet), Siyeç (Ali), Summak (Mustafa), Tabak (Ali), Tamah (Ökkeş), Taşkala (Mustafa), Tazı (Cemil), Tilki (Halil), Topal (Halil), Topuz (Hösen), Taykeş (Mahmut), Tuluk (Hasan), Turfanda (Hasan), Uysal (Kenan), Vabıs (Muharrem), Vahşi (Kadir), Vukuf (Ali), Vampir (Ahmet), Vapur (Ali), Varak (Ahmet), Varil (Mahmut), Varoş (Kazım), Vasat (Halil), Veci (Salih), Vezir (Ahmet), Yosma (Dilek), Yalak (Mahmut), Yavan (Veli), Yobaz (Memik), Zalim (Orhan), Zambut (Ali), Zibar (Ali), Zilli (Fattum), Zukkum (Mustafa).

\subsubsection{Türemiş yapılı lakaplar}

Abbehgil, Adakçı (Ali), Ağzıeğrigil, Antekeli (Mustafa), Arakçı (Duran), Arsız (Kadir), Ayakçı (Şakir), Aynalı (Tahir), Azıkçı (Nail), Badanacı (Osman), Bağırsakçı (Durmuş), Bahçeci (Şı̆ho), Bahtsız

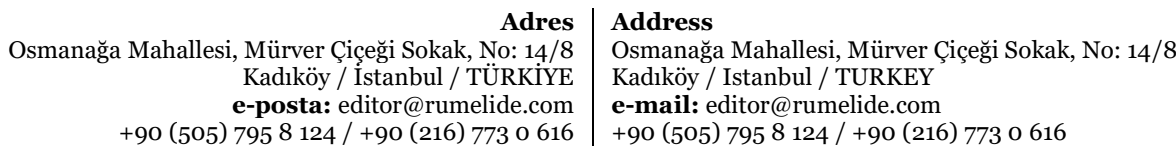


(Hasan), Barhanacı (Ali), Basmanacı (Abdi), Bastacı (Mahmut), Başakçı (Emin), Bavulcu (Ali), Bedelci (Salih), Bekereci (Mehmet), Beleşçi (Halil), Borancı (Osman), Borazancı (Ali), Budamcı (Halil), Canıcebindegil, Ceketçi (İbo), Cilveli (Halil), Çakşır (Halil), Çapaklı (Abdi), Çarpanalı (Cemil), Çı̆̆ırtkan (Kemal), Çıkıkçı (Hösne), Çörtenci (Hakkı), Dalakçı (Nazmi), Dambıracı (Ali), Damızlıkçı (Yaşar), Darabacı (Mahmut), Darakçı (İhsan), Darıcı (Necmi), Davarcı (Mustafa), Davulcu (Bektaş), Depikçi (Durmuş), Dereççi (Mahmut), Devrimci (Kemal), Devrimcigil, Dibekçi (Ahmet), Dilbaz (Duran), Dokumacı (Ali), Dükçü (Şakir), Dürbekeci (Sadık), Düşkün (Halil), Erkek (Ayşe), Ermiş (Şükrü), Eskici (Mehmet), Eskimocu (Salih), Etekli (Ali), Evecen (Ali), Evsiz (Harun), Ezgin (Hasan), Fahreci (Kamil), Fırıldak (Ali), Fırıncı (Halil), Gazozcu (Ali), Gemici (Adil), Gevrek (Hasan), Gezer (Recep), Gezgin (Halil), Gözcü (Ali), Gülcü (Nedim), Güleç (Ali), Haketçi (Mehmet), Hancı (Kemal), Hapsacı (Yaşar), Hasırcı (Habip), İğneci (Şefo), Kalaycı (Ahmet), Kebapçı (Yaşar), Kefizli (Ahmet), Kömürcü (Arap), Körükçü (Mustafa), Külekçi (Ahmet), Kürtüncü (Mahmut), Lambacı (Mehmet), Levhacı (Halil), Lokumcu (Osman), Löküsçü (Macit), Mantocu (Hayri), Marazlı (Sadık), Mastarcı (Eyüp), Mızıkacı (Hasan), Nahırcı (İzzet), Nalıncı (Hikmet), Nedametli (Cuma), Nergizci (Hasan), Nesepçi (Osman), Neyzen (Kemal), Pasaklı (Seval), Perdeci (Hayrettin), Pirci (Mansur), Pişkin (Ali), Postçu (Kadir), Salak (Necmi), Savcı (Güler), Sinekli (Ali), Sülükçü (Durmuş), Süslü (Ahmet), Şahbaz (Mustafa), Tablacı (Ali), Taslak (Kadir), Tepirci (Ali), Tuvarlak (Zeko), Uğurlu (Halil), Ukçursuz (Mesut), Umar (Hasan), Urlu (Ahmet), Uyaran (Kemal), Uzun (Şükrü), Ürkek (Bekir), Yalancı (Âdem), Yallı (Mehmet), Yamaklı (Zeki), Yangın (Leyla), Yapıcı (Salih), Yıkımcı (Hasan), Yumuk (Akif), Yüncü (Ali), Zambırlı (Celal), Zulacı (Tahir), Zurnacı (Bektaş).

\subsubsection{Birleşik yapılı lakaplar}

Abuosmanoğlu (Vedat), Akıllı Teypçi, Altındiş (Mehmet), Aşcığlu (Hüseyin), Ayıboğan (Halil), Ayrancı Pampal (Hasan), Bekçibaşı (Mahmut), Çalgıcı Kör (Elif), Çatpat (İhsan), Çeksündür (Mahmut), Çıtkırıldım (Ömer), Dabanıböyük (Hamza), Dağdelisi (Durmuş), Döşekcibacı (Ayşe), Fosayak (Necmi), Götükara (Tahir), Gazioğlu, Gelgit (Ahmet), Gergef (Ali), Gülkurusu (Ahmet), Heryeri (Mehmet), Hoşaf (Osman), İncirkuşu (Kerem), Karaoğlan (Salih), Kıçıpis (Ali), Kıçkıç (Ali), Kırdök (Ali), Mintancı (Bekir), Nalbant (Ahmet), Nallışeytan (Gürsel), Narçiçeği (Ali), Sarhoş (Nail), Sarıbaş (Mustafa), Şiltelioğlu (Mehmet), Tekdaşşak (Mustafa), Tintin (Mustafa), Uzunoğlu (Mennan), Vakkas (Ökkeş), Zampara (Necmi).

\subsection{Köken bakımından lakaplar}

\subsubsection{Tamamı Türkçe lakaplar}

Adakçı (Ali), Ağzıeğrigil, Altındiş (Mehmet), Aşçıŏlu (Hüseyin), Âşık (Ahmet), Ayakçı (Şakir), Ayıboğan (Halil), Azıkçı (Nail), Baba (Reşit), Bağırsakçı (Durmuş), Barak (Ali), Başakçı (Emin), Bekçibaşı (Mahmut), Bitirim (Celal), Bodur (Ali), Barancı (Osman), Borazancı (Ali), Böke (Mustafa), Budama (Halil), Burgu (Necmi), Civelek (Hasan), Cücük (Hösen), Çakır (Ahmet), Çakşır (Halil), Çamur (Şevket), Çapaklı (Abdi), Çapıt (Abdi), Çarpanalı (Cemil), Çatpat (İhsan), Çeksündür (Mahmut),Çelet (Ali), Çerçi (Hasan), Çığırtkan (Kemal), Çıkıkçı (Hösne), Çıtkırıldım (Ömer), Çolak (Tahir), Çökelek (Abuş), Dabanıböyük (Hamza), Dağdelisi (Durmuş), Dalakçı (Nazmi), Dambıracı (Ali), Damızlıkçı (Yaşar), Dandik (Vedat), Darakçı (İhsan), Darıcı (Necmi), Davarcı (Mustafa), Depikçi (Durmuş), Deve (Şükrü), Devrimci (Kemal), Devrimcigil, Dibekçi (Ahmet), Dilbaz (Duran), Dokumacı (Ali), Döşekcibacı (Ayşe), Düşkün (Halil), Ebe (Şerefe), Erkek (Ayşe), Ermiş (Şükrü), Eskici (Mehmet), Eşşek (Sülo), Etekli (Ali), Evecen (Ali), Evsiz (Harun), Ezgin (Hasan), Fırıldak (Ali), Fiskos (Naciye),

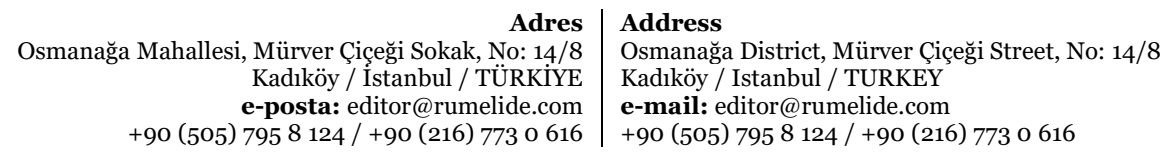


Fosayak (Necmi), Götükara (Tahir), Gelgit (Ahmet), Gemici (Adil), Geviş (Duran), Gevrek (Hasan), Geyik (Ahmet), Gezgin (Halil), Gözcü (Ali), Güleç (Kâmil), Gürgen (Âdem), Heryeri (Mehmet), İğneci (Şefo), İngiliz (Mahmut), Kalaycı (Ahmet), Kambur (Hasan), Karaoğlan (Salih), Kaşmer (Murat), Kazan (Ali), Kelek (Halil), Kıçıpis (Ali), Kıçkıç (Halil), Kırdök (Ali), Kız (Salih), Köçek (Ali), Kömürcü (Arap), Körükçü (Mustafa), Kurşun (Ahmet), Külekçi (Ahmet), Kürt (Ahmet), Kürtüncü (Mahmut), Laz (Yaşar), Loğ (Mahmut), Lök (Hasan), Nahırcı (İzzet), Öküz (Ahmet), Pasaklı (Seval), Paşa (Cemal), Peltek (Kemal), Pire (Mahmut), Pissik (Abdi), Pişkin (Ali), Porsuk (Muzaffer), Sağır (Nafi), Sakar (Mustafa), Sarı (Tahsin), Sarıbaş (Mustafa), Semiz (Mustafa), Sinekli (Ali), Soku (Ali), Solak (Necmi), Sülükçü (Durmuş), Süslü (Ahmet), Şaşı (Ahmet), Şiltelioğlu (Mehmet), Tekdaşşak (Mustafa), Tepirci (Ali), Tilki (Halil), Tintin (Mustafa), Topal (Halil), Tuluk (Hasan), Tuvarlak (Zeko), Uğurlu (Halil), Ukçursuz (Mezut), Umar (Hasan), Urlu (Ahmet), Uyaran (Kemal), Uysal (Kenan), Uzun (Şükrü), Uzunoğlu (Mennan), Ürkek (Bekir), Vakkas (Ökkeş), Yosma (Dilek), Yalak (Mahmut), Yalancı (Âdem), Yallı (Mehmet), Yamalıklı (Zeki), Yangın (Leyla), Yapıcı (Salih), Yavan (Veli), Yıkımcı (Hasan), Yobaz (Memik), Yumuk (Akif), Yüncü (Ali), Zıbar (Ali), Zilli (Fattun), Zulacı (Tahir).

\subsubsection{Tamamı yabancı lakaplar}

Abbehgil, Akıllı Teypçi, Alafranga (Halil), Alman (Hanifi), Amud (Ali), Antekeli (Mustafa), Antika (Necmi), Arakçı (Duran), Arap (Hasan), Arsız (Kadir), Asfalt (Mıstık), Ataş (Ali), Avare (Hikmet), Ayar (Ali), Aynalı (Tahir), Ayyaş (Bedri), Badanacı (Osman), Bafon (Necmi), Bahçeci (Şıho), Bahdeniz (Celal), Bahtiyar (Akif), Bahtsız (Hasan), Barhanacı (Ali), Barmil (Mehmet), Bavulcu (Ali), Baytar (Mustafa), Bedelci (Salih), Behlek (Şakire), Bekereci (Mehmet), Beleşçi (Ali), Berduş (Duran), Beton (Cemil), Beyaz (Tayfun), Canbaz (Mecit), Canıcebindegil, Cilveli (Halil), Çeketçi (İbo), Çepik (Zeki), Çörtenci (Hakkı), Dabaz (Habip), Dama (Yusuf), Darakçı (Mahmut), Davulcu (Bektaş), Debbe (Ali), Debbağ (Ömer), Dellek (Ahmet), Dereççi (Mahmut), Devriş (Nayll), Dükçü (Şakir), Dürbekeci (Sadık), Dürüst (İbrahim), Efendi (Ağa), Erbap (Halit), Eskimocu (Salih), Eskort (Necmi), Esvet (Recep), Falcı (Güler), Fahreci (Kamil), Farfarı (Yusuf), Fennnüs (Nuri), Ferik (Hasan), Fesat (Tahir), Filik (Zeki), Fodul (Ali), Foto (Ahmet), Füze (Hacı), Garip (Mahmut), Gavur (Halil), Gazozcu (Ali), Gergef (Ali), Gülcü (Nedim), Hafız (Hikmet), Haketçi (Mehmet), Halle (Mehmet), Hancı (Kemal), Harami (Necmi), Haruf (Ali), Hasırcı (Habip), Hasıt (Mahmut), Hasta (Halil), Hayma (Veli), Hecin (Yusuf), Hoşaf (Osman), Katil (Ahmet), Kebapçı (Yaşar), Kel (İzzetgil), Köşker (Hasan), Lafazan (Celal), Lambacı (Mehmet), Lappa (Ali), Lastikçi (Duran), Levhacı (Halil), Leylek (Mustafa), Lilik (Fero), Loğlaz (Yaşar), Lokumcu (Osman), Lüküsçü (Macit), Makaryos (Mustafa), Malhıta (Zeko), Mantocu (Hayri), Marazlı (Sadık), Maskara (Necmi), Mason (Ali), Mastarcı (Eyüp), Mastika (Necla), Mestan (Mahmut), Mızıkacı (Hasan), Mintancı (Bekir), Mostura (Serpil), Nakkaş (Halil), Nalbant (Ahmet), Nalıncı (Hikmet), Nallışeytan (Gürsel), Nazik (Mahmut), Necis (Durmuş), Nedametli (Cuma), Nergizci (Harun), Nesepçi (Osman), Neyzen (Kemal), Papaz (Duran), Paraşüt (Cemil), Parça (Ahmet), Paskil (Hasan), Perdeci (Hayrettin), Pirci (Mansur), Postçu (Kadir), Puşt (Durmuş), Radar (Mahmut), Rafik (Kerim), Rakkas (Ali), Rakkase (Leyla), Robot (Halil), Roket (Mesut), Rolans (Ahmet), Rotuş (Hasan), Rozet (Kamil), Rüküş (Şükrüye), Sarhoş (Nail), Sarraf (Hösen), Siyeç (Ali), Summak (Mustafa), Şahbaz (Mustafa), Tabak (Ali), Tablacı (Ali), Tamah (Ökkeş), Taslak (Kadir), Taşkala (Mustafa), Tazı (Cemil), Topuz (Hösen), Turfanda (Hasan), Turuncu (Halil), Vabıs (Muharrem), Vahşi (Kadir), Vampir (Ahmet), Vapur (Ali), Varak (Ahmet), Varil (Mahmut), Varoş (Kazım), Vasat (Halil), Veci (Salih), Vezir (Ahmet), Vukuf (Ali), Vuslat (Kadir), Zalim (Orhan), Zambırlı (Celal), Zampara (Necmi), Zukkum (Mustafa), Zurnacı (Bektaş).

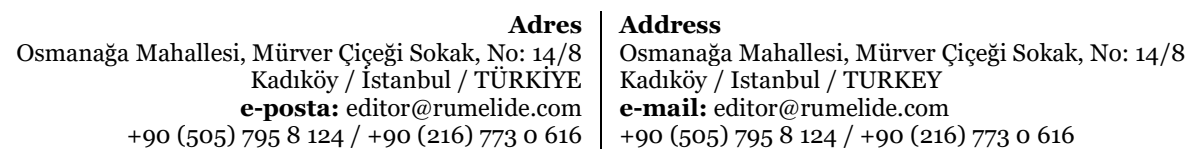




\subsubsection{Türkçe ve yabancı lakaplar}

Abuosmanoğlu (Vedat), Çalgıcı Kör (Elif), Gazioğlu, Gülkurusu (Ahmet), Halle (Mehmet), İncirkuşu (Kerem), Narçiçeği (Ali).

\subsubsection{Kökeni belli olmayan lakaplar}

Ayrancı Pampal (Hasan), Basmanacı (Abdi), Bastacı (Mahmut), Hapsacı (Yaşar), Öhlez (Hoca), Sehlek (Mehmet), Taykeş (Mahmut), Zambut (Ali).

\section{Sonuç}

Literatürde yakıştırma şeklinde de tanımlanan lakap, kişiye öne çıkan bir özelliğine istinaden sonradan verilen ad olarak izah edilebilir. Toplum tarafından kişiye verilen bu ikinci addaki ölçüt; kişinin dinî, etnik ya da fiziksel ve psikolojik özelliklerine bağlı olabileceği gibi meslek, doğduğu yer, eğitim durumu gibi başka pek çok değişkene de bağlı olabilir.

Lakapların dil/kültür ilişkisindeki rolünü ve aynı zamanda Kilis’te kullanılan dilin karakteristiğini tespit etmek maksadıyla sahadan 337 adet lakap derlenmiştir. Bu lakaplardan sadece 14 adedi kadınlara, 323 adedi ise erkeklere verilen lakaplardır. Benzer başka çalışmalarda da tespit edilen bu durum bilhassa küçük ölçekli yerleşim birimlerinde kadının sosyal hayatta erkeğe oranla çok daha az yer alması ile açlklanabilir. Lakaplar da kişilerin sosyal hayattaki faaliyetlerinin neticesinde oluştuğu için kadın ve erkeğin bu bağlamda tespit edilen konumu olasıdır. Ayrıca her iki cinse verilen lakaplar anlam bakımından karşılaştıııldığında erkeğe olumlu-olumsuz, dinî, etnik ve meslek gibi pek çok özelliğine bağlı çeşitli lakaplar verilmesine karşın kadına sadece mesleğine ve toplum tarafından hoş karşılanmayan ahlakî durumuna bağlı lakaplar verilmiştir. Dolayısıyla yörede, kadının kutsiyetinin ve mahremiyetinin fazlasıyla değer gördüğünü söylemek mümkündür.

Hapsacı, Basmanacı, Bahçeci, Dibekçi, Damızlıkçı, Nahırcı gibi lakaplar, ildeki ekonomik faaliyetleri açıklarken üzüm yetiştiriciliği ile ilgili uygulamalara bağlı lakapların bolca kullanılması bu alandaki tarımsal etkinliklerin önemini vurgulamaktadır.

Lakapların temel fonksiyonları olan tanıtma, yüceltme, küçümseme bağlamlarında Kilis'te kullanılan şahıs lakaplarında özellikle olumsuz bir özelliğe bağlı küçümseme durumu; aile lakaplarında ise daha çok tanıtma, hakkında bilgi verme durumu dikkat çekmektedir.

Yörede kullanılan lakapların köken ve yapı gibi dil bilimsel açıdan değerlendirilmesi ile halkın Türkçesinde, coğrafî konumuna da bağlı olarak daha çok Arap toplumuyla kültürel ilişkilerde bulunulduğu için Arapça kökenli pek çok kelimenin varlı̆̆ı söz konusudur. Taykeş, Malhıta, Zambut, Zambırlı, Abbeh, Öhlez, Lilik gibi daha pek çok lakabın henüz Derleme Sözlüğü’nde yer almadığı görülmüştür. Türkçenin sözcük oluşturma yollarında öncelikli tercihin türetme olmasına bağlı olarak lakaplar çoğunlukla türetilerek oluşturulmuştur. Birleşik yapılı lakapların sayısı, basit ve türemiş yapılı lakaplara göre oldukça azdır.

Yapılan bu çalışma ile Kilis ilindeki kültürel doku, önemli dil unsurları olan lakaplar aracıllğı ile somutlaştırılmaya çalışılmıştır. Ayrıca yöredeki Türkçenin karakteristiği açısından ulaşılan verilerdeki çeşitlilik ve hareketlilik bölgedeki ağız araştırmaları çalışmalarının arttırılması gerektiğini göstermektedir.

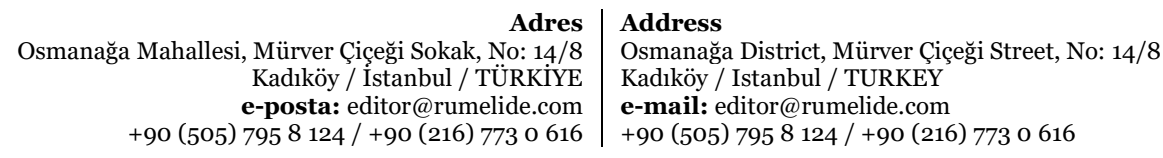




\section{Kaynakça}

(2005). Türkçe Sözlük. Ankara: TDK.

Akçam, Z. (2015). XIX. Yüzyll Kıbrıs Şeriye Sicillerinde Lakap ve Unvanlar, Türkbilig, 29, s.191-208.

Akdağ, Ö. (2014). Çeşmelisebil'de Lakaplar ve 1934 Lakap Kanunu, Tarih, Kültür, Sanat, Turizm ve Tarım Açısından Uluslararası, Sarayönü Sempozyumu, Konya: Selçuk Üniversitesi Türkiyat Araştırmaları Enstitüsü Yayınları s.726-734.

Aksu, A. (2001). Asr-ı Saadet ve Emeviler Döneminde Lakap Takma ve Halifelerin Lakapları, Cumhuriyet Üniv. İlahiyat Fak. Der., 5 (2), s.229-248.

Aktan, F. (1970). Takma Adlar, Folklor, 2 (13-14-15), s. 62-64.

Aydın, M. (2006). Adbilim Açısından Ordu ve Samsun Ağızlarındaki Bazı Lakaplar, Türk Dilleri Araştırmaları, 16, s.25-47.

Boyraz, Ş. (1998). Lakaplar Konusunda Bazı Dikkatler ve Bir Yare Örneği, Türklük Bilimi Araştırmaları, 7, s. 107-138.

Coşar, M. (2003). Trabzon'da Kullanılan Lakaplar Üzerine Bir Derleme / Değerlendirme, TDAY Belleten, I-II, s.27-40.

Devellioğlu, F. (2012). Osmanlıca-Türkçe Ansiklopedik Lûgat, Ankara: Aydın Kitabevi Yayınları.

Doğaner, Y. (2007). Atatürk Dönemi Türkiyesi'nde Sosyo-Kültürel Değişim, Uluslararası Asya ve Kuzey Afrika Çalışma Kongresi ICANAS, 38, s.235-260.

Kabak, T. (2014). Lakaplar ve Uzunburç Kasabasında Lakap Verme Geleneği, Acta Turcica, 5 (1-1).

Kardaş, C. (2018). Muş İli Merkezinde Kullanılan Erkek Lakapları, Motif Akademi Halkbilimi Dergisi, 11 (23), s.207-226.

Kibar, O. (2017). Ağaköy Lakapları - Köy Lakapları Üzerine Bir Tasnif Denemesi - Biga: Yarım Elma Yayınevi.

Menekşe, M. (2017). XIX. Yüzyll Ortalarında Bodrum Kasabasında Kullanılan Lakaplar (Hane Sahipleri Listesi ile Birlikte). Uluslararası Sosyal Araştırmalar Dergisi, X(54), s. 307-329.

Menekşe, M. (2019). Türk Kültüründe Kişi Adları ve Lakaplar: XIX.Yüzyıl Ortalarında Seyitgazi Kasabasında Kullanılan Kişi Adları ve Lakaplar Üzerine Bir İnceleme, Türkiyat Araştırmaları Enstitüsü Der., 65., s. 303-331.

Oğuz, Ş. ve Oğuz İ. (2008). Lakap Verme Geleneğinde Manisa İli Demirci İlçesi Örneği, 38, ICANAS (Uluslararası Asya ve Kuzey Afrika Çalışmaları Kongresi), Ankara: Atatürk Kültür, Dil ve Tarih Yüksek Kurumu Başkanlığı.

Özdemir, S. ve Erdem R. (2016). Akademik Örgütlerde İdari Personel Arasında Kullanılan Lakaplar Üzerine Bir Çalışma, Süleyman Demirel Üniv. Sos. Bil. Enst. Der., 3 (25), s. 247-261.

Özkan, N. (2016), Adlandırma Yöntemi Olarak Lakaplar ve Büyükkışla’daki Örnekleri, I. Uluslararası Bozok Sempozyumu Bildiri Kitabı, 3, s.180-189.

Şakar, S., Ö. Takma Ad veya Lakap Olarak Kullanılan Bazı Hayvan Adları, Türk Kültürü, XLIV (515517), s.107-115.

Semih, M. (1993). Türk Edebiyatında Mahlaslar, Takma Adlar, Tapşırmalar ve Lakaplar, İstanbul: Anahtar Kitaplar Yayınevi, s.84.

Sevinç, F. (2019). Tezkirelerde Şair Tanıtımlarında Kullanılan Lakaplara Dair, Iğdır Üni. Sosyal Bil. Der. , 19 s.309-341.

Şimşek, K. (2018). Osmanlı Devleti’nde Engelliler İçin Kullanılan Tabir, Lakap ve Sıfatlar, Belge, 15 (1), s.728-740.

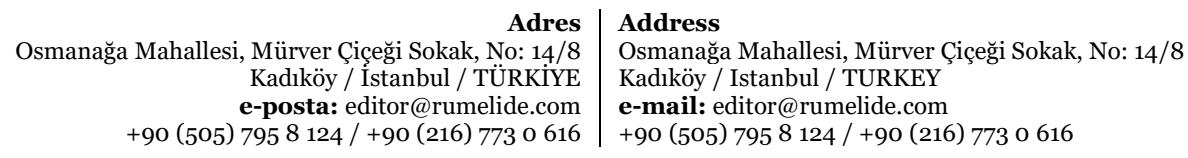


Tan, N. (2016). Rodoslu Türklerin Lakapları Bağlamında Ad Biliminde Lakapların Önemi, Türk Dili, CX (777), s.103-112.

Tekin, Z. ve Ceylan, H. (2017). Safranbolu Şeriye Sicillerinde Geçen Eşya, Lakap ve Yer İsimleri, Journal of History Culture and Art Research, 6 (6), s.377-402.

Toygar, K. (1979). Türkiye'de Öğrencilerin Öğretmenlerine Taktıkları Adlar, (Türk Halkbilim Araştırmaları Yıllığı 1977), Ankara: Mifad Yayınları, s.223-237.

Üçer, M. (1992). Kimlerdensiniz? (Sivas’ta Adlar, Lakaplar ve Aile Adları Üzerine), Kızılırmak, 1(12), s.411.

Ylldızkaya, Ö. F. (2014). Emirdağ’da Lakaplar Üzerine Bir Araştırma, Acta Turcica, 6 (1), s. 1-16.

\section{İnternet erișimleri}

www.islamansiklopedisi.org.tr, Erişim Tarihi: 19.04.2020.

www.kubbealtılugati.com, Erişim Tarihi: 20.04.2020.

www.etimolojiturkce.com, Erişim Tarihi: 10.042020.

www.nisanyansozluk.com, Erişim Tarihi: 21.04.2020.

www.almanca-turkcesozluk.com, Erişim Tarihi: 27.04.2020.

www.tdk.gov.tr, Erişim Tarihi: 27.04.2020.

www.sozluk.gov.tr, Erişim Tarihi: 27.04.2020.

\section{Sözlü kaynaklar}

KK-1: Merhum Hüseyin Yeler, Kilis 1964, Zabita. (24.07.2020)

KK-2: Abdurrahim Seyrekbasan, Kilis 1960, İmam. (30.04.2020)

KK-3: Cemalettin Şiltelioğlu, Kilis 1998, Üniversite Öğrencisi. (22.04.2020)

KK-4: Asiye Polat, Kilis 1978, Ev Hanımı. (04.06.2020)

KK-5: Adil Davutoğlu, Suriye 1954, Emekli Tercüman. (27.04.2020) ${ }^{2}$

\section{Kisaltmalar}

Alm. : Almanca

Ar. : Arapça

Erm. : Ermenice

Far. : Farsça

Fr. : Fransizca

İng. : İngilizce

İt. : İtalyanca

Mac. : Macarca

Yun. : Yunanca

Rum. :Rumca

Kaynakça kısmında belirtilen sözlüklerden kökeni tespit edilemeyen ve halk ağzında kullanılan lakaplar ile ilgili bilgiler Arapça-Farsça ve Türkçesinin çok iyi düzeyde olmasına bağlı olarak KK-5'ten derlenmiştir.

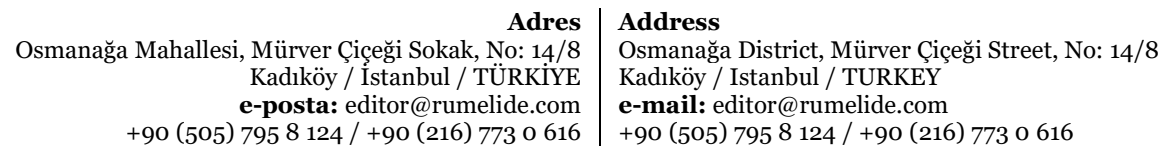


EK-1: Lakapların anlam, yapı ve köken bakımından istatiksel grafikleri

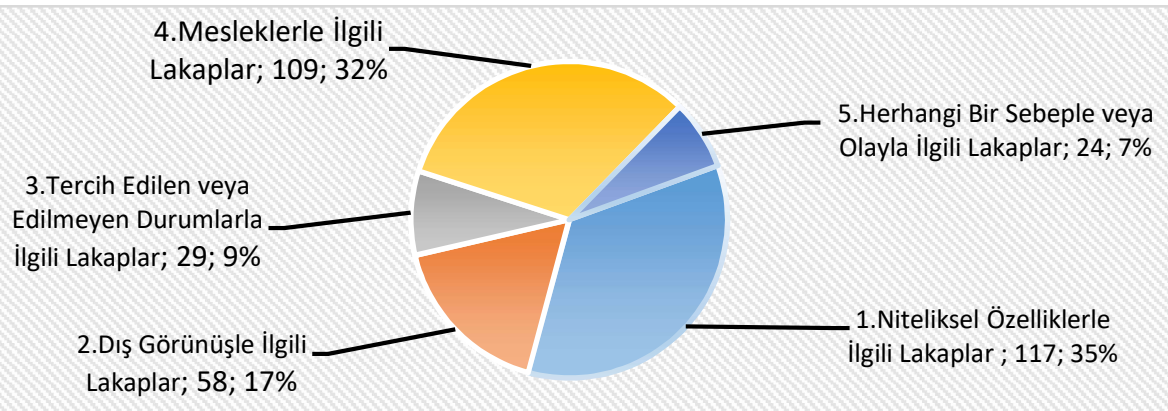

Grafik 1. Anlam bakımından lakaplar

Grafik 1'de 117 adet olan niteliksel özelliklerle ilgili lakaplardan 2'si etnik kökene bağll, 4'ü din ile münasebete bağlı, 13’ü aile, akraba, soy ile ilgili durumlara bağll, 5’i yaşam biçimine bağll, 1’i maddi duruma bağll, 21’i yetenek ve becerilere bağll, 25’i mizaca bağll, 5 ’i olumlu tutum ve davranışlara ve 35 'i olumsuz tutum ve davranışlara bağlı lakaplar; 58 adet olan dış görünüşle ilgili lakaplardan 38 'i fizikî duruma bağlı, 10’u kıyafet, ayakkabı vb. özelliklere bağlı, 8’i dış görünüşteki bir engel veya kusura bağlı, 1'i ünlü birine benzemeye bağlı lakaplar; 29 adet olan tercih edilen veya edilmeyen durumlara bağlı lakaplardan 1’i hoşa gitmeyen durumlara bağlı lakaplar; 109 adet mesleklerle ilgili lakaplardan 35’i meslek adına bağll, 65’i satılan ürüne veya üretilen malzemeye bağlı, 11’i de mesleğin icra edildiği alete bağlı lakaplar ve 24'ü ise herhangi bir sebeple veya olayla ilgili lakaplardır.

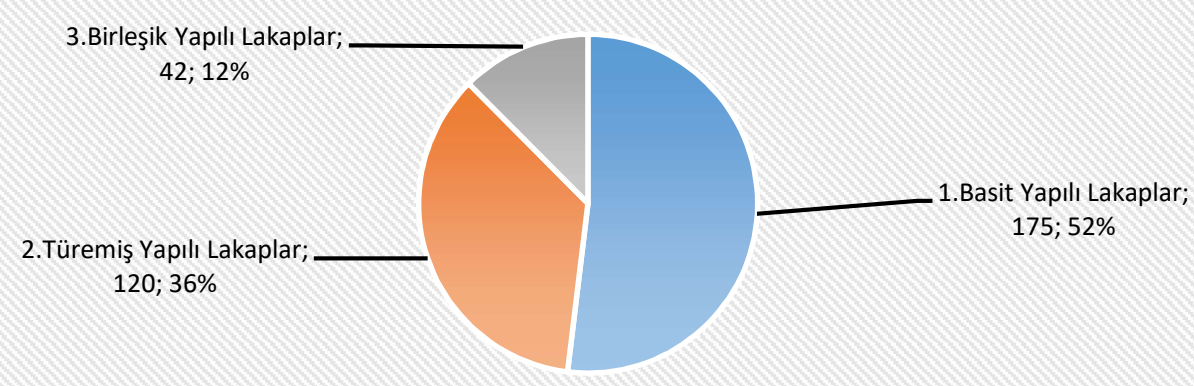

Grafik 2. Yapı bakımından lakaplar

Grafik 2'de görüldüğü gibi lakapların, yapı bakımından Türkçenin sözcük oluşturmadaki karakteristiğine uygun olarak en çok basit ve türemiş ve sınırlı sayıda da birleşik şekilde oluşturulduğu görülmektedir.

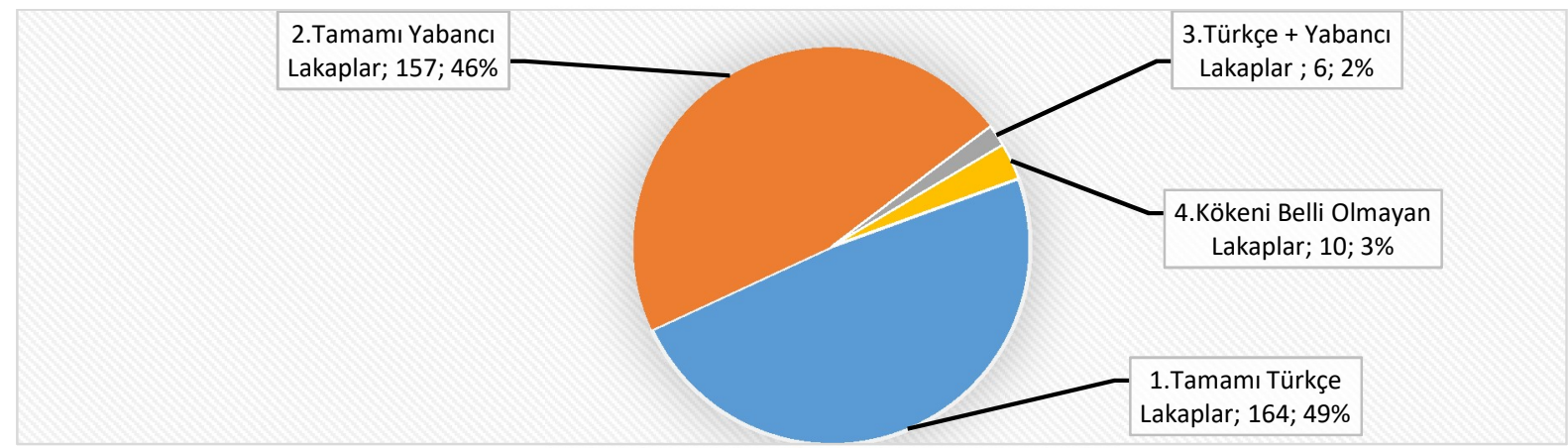

Grafik 3. Köken bakımından lakaplar

\begin{tabular}{r|l} 
Adres & $\begin{array}{l}\text { Address } \\
\text { Osmanağa Mahallesi, Mürver Çiçeği Sokak, No: 14/8 }\end{array}$ \\
Osmanağa Mahallesi, Mürver Çiçeği Sokak, No: 14/8 \\
Kadıöy / İstanbul / TÜRKiYE & Kadıköy / Istanbul / TURKEY \\
e-posta: editor@rumelide.com & e-mail: editor@rumelide.com \\
+90 (505) 7958124 / +90 (216) 773 o 616
\end{tabular}


Grafik 3’te 157 adet olan tamamı yabancı lakaplar içerisinde köken dağılımı; Arapça 72, Farsça 44, Fransızca 23, İtalyanca 7, Rumca 4, Yunanca 3, İngilizce 2, Almanca 2, Macarca 1 şeklindedir. Sinır komşuluğuna bağlı en çok tercihin Arapça ve Farsça olması doğal iken; 23 adetle Fransızcanın üçüncü sırada yer alması, Kurtuluş Savaşı esnasında bu bölgenin Fransızlar tarafından işgal edilmesi ile ilişkili olabilir. Ayrıca Türkçe ve yabancı kökenli lakapların tamamı Arapça+Türkçe ve Farsça+Türkçe şeklindedir.

\section{EK-2: Lakaplar sözlüğü}

Abo+osman+oğlu Şaşırma ünlemi + Kişi Ar. Kişi adı.

Abbeh+gil Far. Abiye

adak+çı Adayan kişi.

ağzı+eğri+gil Ağzında eğrilik olan kimse.

akıllı teypçi Ar. akl + İng. tape Elektronik beyinli cihazları satan kimse.

alafranga İt. Avrupa uygarlı̆̆ıı benimsemiş, Avrupa eğitimiyle yetişmiş (kimse).

Alman Fr. Cermen soyundan olan halk.

altın+diş Dişi altın kaplı olan kimse.

amud(Amuda Kalk-) Ar. halk

ağzznda İki eli üstüne dayanarak bacaklarını havada dikey tutmak.

antika İt. antico Tarihsel bir döneme ait olan.

arak+çı Araklayan, çalan (kimse).

Arap Ar. Ârap Orta Doğu ile Kuzey Afrika'nın büyük bir bölümünde yaşayan halk ve bu halkın soyundan olan kimse.

Ar+sız Ar. âr Utanması, sıkılması olmayan, yllışı, yüzsüz (kimse).

asfalt Fr. asphalte Ana maddesi katran olan ve yolların kaplanmasında kullanılan karışım.

aşçı+oğlu Yemek pişirmeyi meslek edinen kimsenin çocuğu.

aşık kemiği halk ağzında Küçükbaş hayvanların ayak kemiklerinden yapılan bir tür oyun aleti.

attar Ar. attâr. Yanlarında bir adet eşek veya katırla köy köy dolaşan satıcı.

ataş Far. ateş halk ağzında Yanıcı cisimlerin tutuşmasıyla beliren ısı ve ışık, od, nâr

avere(avare) Far. halk ağzında İşsiz, işsiz güçsüz, başıboş, aylak

ayak+çı Gezici satıcı, çerçi.

ayar Ar. iyâr Bir aygıtın gereken işi yapabilmesi durumu.

ayı+boğan Ayıya gücü yetecek kadar (kimse).

ayna+lı Far. âyîne Aynası olan.

ayrancı pampal(?) halk ağzında Şişman.

ayyaş Ar. ayyâş̧ İçkiye düşkün, içkici, içici, keş(II), küplü, bekri.

azıkçı Yanında yiyecek bulunduran kimse.

baba Koruyucu, babalık duyguları ile dolu kimse.

badana+cı Fr. badigeonne Geçimini badana yapmakla kazanan kimse.

bafon Alm. fakfon Bakır, nitel ve çinkodan oluşan gümüş görünümünde bir alaşım.

bağırsak+çı halk ağzında Eti yenen hayvanların erlerini alıp satan kimse.

bahçe+ci Far. bagce Çiçek, ağaç ve sebze yetiştirme işiyle uğraşan kimse.

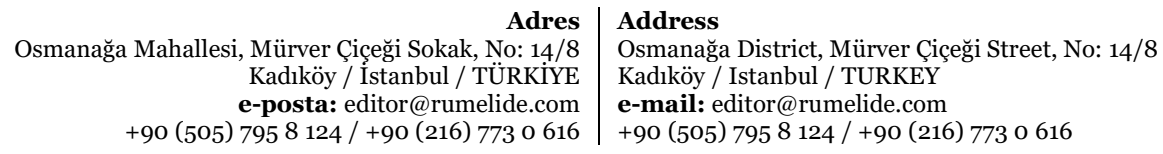


bahteniz(maydanoz) Rum. halk ağzında Maydanozgillerden, yenmek için yetiştirilen, 50-80 santimetre uzunluğunda, ufak yeşil ve parçalı yapraklı, hoş kokulu, otsu bir bitki.

baht+sız Far. Bahtı kötü olan, mutsuz, talihsiz, kadersiz, kötü talihli, bibaht.

bahtiyar Far. bahtiyâr Mutlu.

burnu+büyük Burnu ölçü olarak büyük olan kimse.

barak Türk boyu. halk ağzında Tüylü, kıllı. cuha.

baran Far. bârân Yağmur halk ağzında İki zeytin ağacının arası.

barhanacı Far. bâr + hâne Kafile, küçük kervan.

barmil Fr. baril halk ağzında Çoğunlukla sıvı maddeleri koymak için kullanılan, metalden yapılmış, silindir biçiminde, üstü kapalı kap.

basmana+cı(?) halk ağzında Üzümden pekmez yapan kimse.

basta+cı(?) halk ağzında Konfeksiyon işiyle uğraşan kişi.

başak+çı Tarlalarda kalmış başakları veya bağlarda dökülmüş meyveleri toplayan kimse.

baytar Ar. Veteriner hekim.

bavul+cu İt. baule Bavul yapan veya satan kimse.

bedel+ci Ar. halk ağzında Faizci, tefeci.

bekçi+başı Bir şeyi veya bir yeri bekleyip korumakla görevli en yüksek kimse.

bekere Ar. Bir ucu kovalı, aşağıdan yukarıya çekmeye yarayan el yapımı vinç.

beleş+çi Ar. bilâşey Bedavacı.

beton Fr. Çimentonun su yardımıyla kum, çakıl vb. Maddelerle karışması sonucu oluşan sert, dayanıklı, bağlayıcı yapı malzemesi.

berduş Far. berdûş Başıboş, serseri kimse.

beyaz Ar. beyâz Ak, kara, siyah karşıtı.

bitirim Açıkgöz, işini bilen kimse.

bodur Enine göre boyu kısa ve tıknaz.

boynu+yoğun+gil halk ağzında Boynu etli ve kalın olan kimse.

borazan+cı T. boru + Far. -zen Borazan çalan kimse.

böke Kahraman, güçlü kimse.

budam+cı Budama işini yapan kimse.

burgu Delik açmaya yarayan delgiye takılı sarma, yivli, keskin, çelik alet.

canbaz(cambaz) Far. cânbâz Yerde ve tel, at, bisiklet, ip vb. üzerinde dengeye dayanan, tehlikeli, heyecan verici gösteriler yapan kimse, akrobat.

canı+cebinde+gil Far. cân+Ar. ceyb Çıtkırıldım.

cilveli Far. Cilvesi olan, cilve yapan, cilvekâr, cilvebaz.

civelek Canlı, neşeli ve sokulgan, Halk ağzı. Ufak tefek.

cücük halk ağzında Kuş yavrusu.

çakır halk ağzında El çabukluğuyla yapılan hırsızlık.

çakşır < çakşak Paça bölümü diz üstünde veya diz altında kalan bir tür erkek şalvarı.

çalgıcı kör çalgıcı + Far. kûr Çalgı çalmayı kendine meslek edinmiş kimse.

çamur Su ile karışıp bulaşır ve içine batılır duruma gelmiş toprak, balçık.

çapaklı Çapağı olan.

çapıt < çapgut halk ağzında Paçavra, bez parçası.

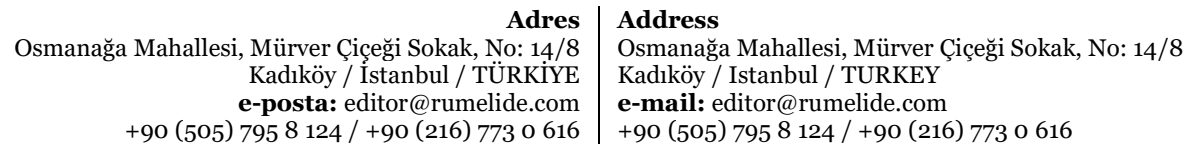


çelet Ar. veled halk ağzında Yaramaz, çılgın, ipte durmaz.

Çarpanalı(?) halk ağzında Eskiden plastik pabuca verilen isim.

çatpat Çatapat.

çeketçi(ceketçi) Fr. jaquette halk ağzında Erkeklerin ve kadınların giydiği, genellikle önden düğmeli, kalçayı örten, kollu üst giysisi.

çek+sündür Bir şeyi çekerek uzatmak, esnetmek.

çepik Far. çâbuk halk ağzında Aceleci, ivecen kimse. çerçi Köy, pazar vb. yerlerde dolaşarak ufak tefek tuhafiye eşyası satan kimse.

çı̆̆ırtkan Bir olayı, bir haberi yüksek sesle çevreye duyuran kimse.

çıkık+çı Çıkıkları düzelten kimse.

çıt+kırıldım Aşırı incelik, dayanıksızlık ve çekingenlik gösteren (kimse).

çolak Eli veya kolu sakat olan kimse.

çökelek Yağı alınmış süt veya yoğurdun kaynatılmasıyla elde edilen bir peynir türü, kesik, ekşimik, torak.

çörten+ci Erm. çur(su) + Erm. ortan(oluk) Dam çevresindeki yağmur sularını oluklardan alıp duvar temelinden uzağa akıtan, saçak kenarlarından dışarı doğru uzanmış ağaç oluk.

dabanıböyük(tabanı+büyük) halk ağzında Ayak tabanı büyük olan kimse.

dabaz Ar. tabaklama debagat halk ağzında. Deri üzerinde olan ve kaşıntı yapan kırmızı kabarcıklar, kurdeşen.

dă̆+delisi halk ağzında Her daim dağlarda gezen kimse.

dama İt. da'ma Karelere ayrılmış zemin üzerinde on altı taşla iki kişi arasında oynanan oyun dambıra+cı(dombracı) halk ağzında İki telli bir Türk çalgısı.

damızlık+çı Pekmez, yoğurt, peynir vb. şeyleri yapan kimse.

dandik Düşük nitelikli.

daraba+cı Ar. darrâba Câmekanı kapatan tenekeden kıvrımlı vitrin muhafazasıı..

darak+çı(tarakçı) halk ağzında Tarak yapan veya satan kimse.

darı+cı Bu bitkinin buğday yerine besin olarak kullanılan tohumunu satan kişi.

davar+cı Koyun veya keçi sürüsüyle uğraşan kimse.

davul+cu Ar. tabl Davul çalan kimseç

debbağ Ar. halk ağzında Deri işleyen ve onu ayakkabı haline getiren kimse.

debbe Ar. hayvan, yük hayvanı halk ağzında Kulplu ve ağzı kapaklı bakırdan su kabı, güğüm.

dellek(tellak) Ar. tellâk halk ağzında Hamamda hizmet eden ve erkek müşterileri yıkayan erkek.

depikçi(tekmeci) halk ağzında Ayakla vurma işini yapan kimse.

dereççi Ar. dereç halk ağzında Merdiven, Bu işle uğraşan kişi.

devriş < derviş Far. Bir tarikata girmiş, onun kurallarına ve törelerine bağlı kimse, alperen, alçak gönüllü ve her şeyi hoş gören kimse.

deve Geviş getiren memelilerden, boynu uzun, sırtında bir veya iki hörgücü olan, yük taşımakta kullanılan hayvan.

dibek+çi halk ağzında İçinde kahve ve benzeri şeylerin dövüldüğü büyük havan.

dil+baz dil+Far. -baz Güzel söz söyleyen, konuşmasıyla ikna eden.

dolak+çı halk ağzında Başörtüsü, yazma.

dokuma+cı Kumaş dokuyan veya dokuma ticareti yapan kimse, dokuyucu

döşek+çi+bacı Yatak yapan kimse.

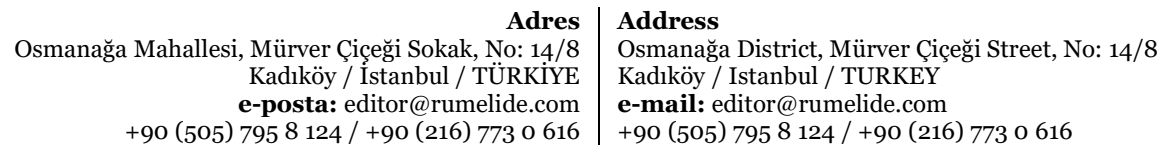


dükçü Usta. halk ağzında Attığını vuran, nişancı.

dürbekici(darbukacı) Ar. darabukka Darbuka çalan kimse.

dürüst Far. Sözünde ve davranışlarında doğruluktan ayrılmayan, doğru (kimse).

düşkün Yoksulluk sebebiyle mutluluk ve refahını yitirmiş:

ebe Doğum işini yaptıran kadın.

efendi Rum. Günümüzde bey unvanından farklı olarak özel adlardan sonra kullanılan ikinci derecede bir unvan.

erbab Ar. erbâb Bir işten anlayan, bir işi iyi yapan kimse.

erkek Yetişkin adam, bay, er kişi.

ermiş Dinî inançlara göre kendisinde olağanüstü manevi güç bulunan kişi, eren, evliya, veli.

eski+ci Her türlü eski eşya alım satımıyla uğraşan kimse.

eskimocu Fr. esquimaux Şekerli suya meyve tozu katılarak yapılan dondurma.

eskort Fr. escorte Koruma aracı.

esvet Ar. kara halk ağzında Kara.

eşşek(eşek) halk ağzında Akıllı olmayan kimse. Atgillerden, uzun kulaklı binek ve hizmet hayvanı, merkep, karakaçan, uzun kulaklı.

etek+li Bedenin belden aşağısına giyilen, değişik biçimlerde, genellikle kadın giysisi, eteklik.

evecen < ivecen halk ăgzında Aceleci.

ev+siz Yaşamını sokaklarda sürdüren.

ezgin halk ağzıında Çok cefa görmüş.

fahre+ci (?) halk ağzında Eskiden çamurdan çanak, çömlek yapan kimse.

fal+cı Ar. fâl Fala bakmayı kendine geçim yolu yapan kimse.

farfari Ar. ferfere halk ağzında Çok konuşan kimse.

fennüs Ar. fener, fenus halk ağzında Gemici feneri.

ferik Kümes hayvanlarının civcivlikten çıkmış yavrusu, piliç.

fesat Ar. fesâd Karışıklık, kargaşalık, ara bozuculuk.

firıldak Rüzgârla dönen, çember biçiminde çocuk oyuncağı.

firın+cı Rum. Fırın işleten kimse.

filik Far. taze halk ağzında vücudunda hiç kıl olmayan, bembeyaz kimse.

fiskos Başkalarının duyamayacağı biçimde gizli ve alçak sesle konuşma, dedikoducu.

fodul Ar. fudûl halk ağzında Kısa olan kimse.

fos+ayak halk ağzında Dolandırıcı.

foto(Fotoğraf) Fr. photographe Çeşitli araç ve malzeme kullanarak görüntüyü özel bir yüzey üzerinde sabitleme.

füze Fr. fusee halk ağzında Hızlı.

Gazi+oğlu Ar. gâzî Müslümanlıkta düşmanla savaşan veya savaş yapmış kimsenin oğlu.

$\mathbf{g a z o z}+\mathbf{c u}$ Fr. gazeuse Gazoz yapıp satan kimse.

garip Ar. garîp Kimsesiz, zavallı olan.

gavur Far. Gebr Merhametsiz, acımasız.

gel+git Boşuna gidip gelme.

gemi+ci Gemide çalışan veya gemi işleten kimse.

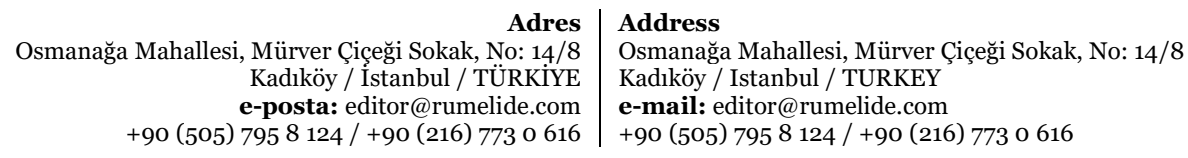


gergef Far. kâr + Ar. keff Üzerine kumaş gerilerek nakış işlemeye yarar, çoğu dikdörtgen biçiminde olan çerçeve.

geveze Çok konuşan, çenesi düşük, gevşek ağızlı, lafçı, lafazan, zevzek, lakırtı ebesi, ağız kavafı, lakırtı kavafı, çene kavafi, cır cır, çaçaron.

geviş Ağızda çiğnenen şey, lokma.

gevrek Kolayca kırlıp ufalanan.

geyik Geyikgillerden, erkeklerinin başında uzun ve çatallı boynuzları olan memeli hayvan.

gezer Çok gezen kimse.

gezgin Gezmek, tanımak, görmek, dinlenmek amacıyla geziye çıkan (kimse), gezici, gezmen, seyyah.

götü+kara Kaba eti kara renginde olan veya boyanan.

göz+cü Gözlemleme veya gözetleme işini yapan kimse.

güleç Her zaman gülümseyen, mütebessim:

gül+kurusu Far. gul Kurutulmuş gül.

gül+cü Far.gul Gül üreten veya alıp satan kimse.

gürgen halk ağzında Sert

güve Kurtçuğu yapağı, yünlü kumaş ve dokuma yiyen pul kanatlllardan bir böcek.

hafiz Ar. hâfiz Kur'an'ı bütünüyle ezbere bilen kimse.

haketçi Ar. hikâye halk ağzında Hikaye anlatan kimse.

halle Ar. leğen, büyük tencere.

han+cı Far. Hân Han işleten kimse.

hapsacı halk ağzında Üzüm şırasından katı pestil yapan kimse.

harami Ar. harâmî Hırsız, haydut.

haruf Ar. Kuzu halk ağzında Erkek koyun.

hayma Ar. hayme halk ağzında Bağ ve bahçelerde çalı çırpıdan yapılan çardak.

hecin Ar. hecîn Çift parmaklılar takımının devegiller familyasından, uzunluğu 3, yüksekliği 2 metre kadar olan, sırtında besin depo etmeye yarayan tek hörgücü bulunan, hızlı yürüyen bir tür memeli. Uzun boylu insan.

her+yeri halk ağzında Her yere herkesten önce giden kimse.

hoşaf Far. hoştâb Meyvenin şekerli suyla kaynatılmasıyla yapılan bir tatlı türü.

iğne+ci İğne yapan kimse.

incir+kuşu Far. encîr Sarıasma da denilen serçe büyüklüğünde sarı bir çeşit kuş.

İngiliz İngiltere halkından olan kimse.

kalay+cı Kap kalaylayan kimse.

kambur Bel veya göğüs kemiğinin eğrilmesi, raşitizm sonucu sırtta ve göğüste oluşan tümsek, kambur zambur.

Kara+oğlan Esmer olan kimse.

kaşmer Soytarı.

katil Ar. katl insan öldüren kimse, cani.

kazan Çok miktarda yemek pişirmeye veya bir şey kaynatmaya yarayan büyük, derin kap

kebap+çı Ar. kebâb Kebap yapıp satan kimse.

kel Far. Saçı dökülmüş olan (kimse).

kelek Olgunlaşmamış, ham kavun.

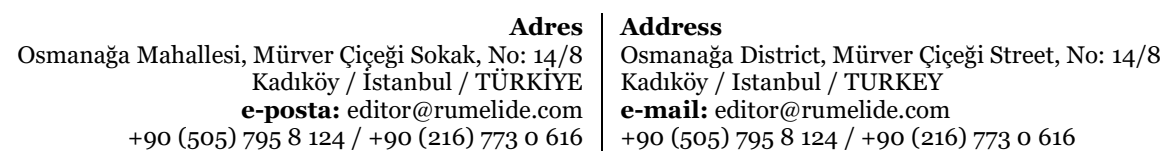


kıç+kıç Kuyruk sokumu bölgesi, kaba et, kaba but, popo, makat.

kıçı+pis Kaba eti leke, toz veya kirle kaplı olan, kirli olan.

kız Dişi.

kır+dök Dikkatsizlik veya öfkeyle birçok şeyin kırılmasına neden olmak.

köçek Kadın kılı̆̆ına girip oynayan erkek.

köşker Far. kevşger Yemenici, ayakkabı tamircisi.

körük+çü Körük yapan veya satan kimse.

kömür+cü Kömür alıp satan veya odun kömürü yapan kimse.

kurşun Tüfek, tabanca vb. hafif ateşli silahlarda kullanılan mermi.

külek+çi Bal, yă̆, yoğurt vb. şeyler koymaya yararayan tahtayla uğraşan.

Kürt Bir topluluk ve bu topluluktan olan kimse.

kürtüncü halk ağzında Semerci.

lafazan Far. lâfzen Geveze.

lamba+cı Yun. lamba Petrol gibi yanıcı bir madde yakarak veya elektrik akımıyla içindeki teller akkor durumuna geçerek ışık veren aleti yapan kimse.

lappa İt. Nişastalı tanelerin, su ile kaynatılarak bulamaç kıvamına getirilmiş durumu.

lastik Fr. elastique Kauçuktan yapılmış.

laz Güney Kafkasyalı bir halk veya bu halktan olan kimse.

levha+cı Ar. levha Levha yapan veya satan kimse.

leylek Far. legleg Leyleksilerden, kışın tropikal Afrika’da yaşayan, siyah telekli, uzun gagalı, uzun bacakll, büyük, beyaz, göçmen kuş.

lilik Far. zllgıt, neşe çı̆̆lı̆̆ halk ağzında Sevinç. (KK-5)

loğ halk ağzında Yollarda, tarlalarda toprağı ezmek veya toprak damlı evlerin üstündeki killi toprağı sert bir katman durumuna getirmek için dam üzerinde yuvarlanan, silindir biçimindeki ağır taş, yuvgu, yuvak.

loğlaz Far. bezelye halk ağzında Fasulyegillerden bir bitki.

lokum+cu Ar. hulküm Şekerli nişasta eriyiğgini pişirip hafif ağdalaştırarak yapılan, küçük küp veya dikdörtgen biçiminde kesilen şekerlemeyi yapıp satan.

lök halk ağzında Yedi yaşından büyük erkek boz deve.

loküs+çü(lüks+çü) Fr. lux halk ağzında Lüks lambası tamiri yapan kimse.

Makaryos Rum. Rum kesimi eski lideri olan Makaryos. Bir şahıs.

malhıta Ar. mahlıta halk ağzında Bir çeşit yemek.

mantocu Fr. manteau Kadın paltosu.

maskara Ar. mashara Eğlendirici, sevimli, güldürücü, soytarı, hoş (kimse).

mason Fr. maçon Masonluk üyesi, farmason.

mastar+cı Ar. mistâr Sıvacı ve duvarcıların cetvel gibi kullandıkları uzun, ensiz ve düz tahta.

mastika Yun. halk ağzında Bir oyun.

marazlı Ar. Maraz Hastalıklı, hasta.

mestan Far. mestâne Sarhoş gibi, kendinden geçmişçesine.

mızıka+cı İt. musica Bandocu.

mintancı Far. nîm+ten Yakasız, uzun kollu erkek gömleği satan kimse.

mostura İt. mostra halk ağzında Makyaj.

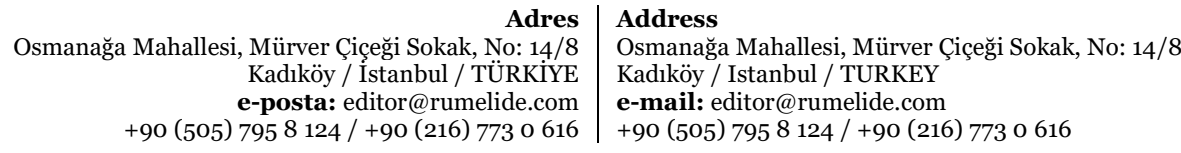


nahırcı Çoban, sığırtmaç.

nakkaş Ar. nakkâş Yapıların duvar ve tavanlarına süslemeler yapan usta, bezekçi.

nal+bant Ar. na'l+ Far. bend Hayvanların ayağına nal çakan kimse.

nallışeytan Ar. na'l + Ar. şeytân halk ağzında Şeytan gibi olan.

nalıncı Ar. naleyn Takunyacı.

nar+çiçeği Far. Nâr+çiçek Parlak kırmızı renk.

nazik Far. nâzuk Başkalarına karşı saygılı davranan.

nedametli Ar. nedâmet halk ağzında Şüpheci.

nesep+çi Ar. neseb Soy, baba soyundan gelen kimse.

necis Ar. necîs Pis, kirli.

nergiz $+\mathbf{c i}$ Far. nergis Nergisgillerden, bazı türlerinde beyaz, bazılarında sarı renkte olan çiçekleri ayrı veya bir kök sap üzerinde şemsiye durumunda, açılmadan önce bir yenle örtülü bulunan, 20-80 santimetre yüksekliğinde, soğanlı bir süs bitkisini satan kimse.

neyzen Far. ney+zen Ney çalan kimse.

öhlez < ehliz(?) halk ağzında Uslu, sakin, hareketleri ağır olan kimse.

öküz halk ağzında Anlayışı kıt olan kimse.

papaz Yun. Üzerinde papaz resmi olan iskambil kâğıdı, rua.

paraşüt Fr. parachure Hava taşıtından veya yüksek bir yerden atılan bir cismin veya atlayan bir insanın kontrollü biçimde yere inmesini sağlayan araç.

parça Far. pârçe Bir bütünden ayrllan, ayrı sayılan veya artakalan şey.

pasak+lı Giyimine veya eşyanın temizliğine, düzenine önem vermeyen (kimse), çapaçul.

paskil < baskül Fr. bascule Kantar.

paşa Osmanlı Devleti zamanında yüksek sivil memurlara ve albaydan üstün rütbede bulunan askerlere verilen unvan.

peltek Dilini dişlerinin arasına alır gibi konuşan ve bu yüzden s, z gibi sesleri kusurlu söyleyen (kimse).

perde+ci Far. Görüşü, ışığı engellemek, bir şeyi gizlemek için pencereye veya bir açıklığın önüne gerilen örtü.

pissik halk ă̆zında Kedi.

pişkin Saygısızca davranarak işini yürüten.

pirci Far. pîr Yaşlı, koca, ihtiyar kimse:

pire Pireler takımından, insanın ve bazı hayvanların kanını emerek yaşayan, iyi sıçradığı için kolay yakalanamayan, küçük, asalak böcek

post+çu Far. pûst Tüylü hayvan derisi satan kimse.

porsuk Sansargillerden, su kıyılarında kazdıkları deliklerde yaşayan, ot ve etle beslenen, pis kokulu, memeli bir hayvan

puşt Far. Güvenilmez, kalleş.

radar İng. Radyo dalgalarının yankısını alarak cisimlerin yerini ve uzaklığını bulabilen, genellikle uçak ve gemilerde kullanılan cihaz

rafik< refik Ar. refik Arkadaş.

rakkas Ar. rakkâs Raksı meslek edinmiş erkek.

rakkase Ar. rakkâse Raksı meslek edinmiş kadın:

robot Fr. Belirli bir işi yerine getirmek için manyetizma ile kendisine çeşitli işler yaptırılabilen otomatik araç

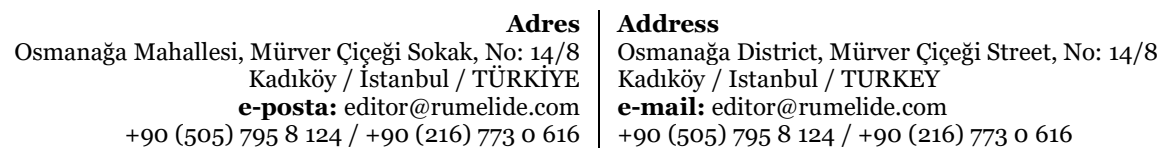


roket İng. rocket Bir çeşit füze

rolans < rölans Fr. relonce Konken, poker vb. oyunlarda ortaya sürülmüş olan parayı artırmak için söylenen söz.

rozet Fr. rosette Yakaya takılmak için çeşitli biçimlerde yapılan, bir kuruluşun sembolü sayılacak genellikle küçük metal nesne.

rotüş(rötuş) Fr. retcuche Düzeltmek amacıyla yapılan değiştirme.

rüküş̧ Ar. rukşe Gülünç bir biçimde giyinip süslenen (kadın).

sağır İşitme duyusundan yoksun, işitmeyen (kimse).

sakar Sık sık küçük, önemsiz kazalar yapan (kimse).

sarhoș Far. ser+hoş Alkollü içki veya keyif verici bir madde sebebiyle kendini bilmeyecek durumda olan (kimse), esrik, mest(I), sermest, başı dumanlı, kafası bulutlu, kafası iyi, kafası dumanlı, kafası kiyak

sarraf Ar. sarrâf Kuyumcu

sarı Yeşil ile turuncu arasında bir renk, limon kabuğu rengi.

sarı+baş Sarı saçlı olan kimse.

Sehlek (?)halk ağznda. Çok yavaş hareket eden. semiz Eti, yağı çok olan, tavlı.

semsek Far. sambûse İçine kıyma, peynir konularak yağda kızartılan bir çeşit pufböreği.

Seydo<Seyit Ar. seyyid Bir topluluğun ileri gelen kişisi.

sinek Çift kanatlılardan, birtakım uçucu böceklerin genel adı.

sinek+li Yüzünden sinek eksik olmayan.

siyeç Ar. çit halk ağzında Tarla ve bağ çevresine çekilen çalı vb. çit. (KK-5)

soku Taş dibek.

solak Genellikle sol elini kullanan kimse.

summak Ar. summâk Dağlarda yetişin ekşi bitki.

sülük Sülüklerden, tatlı sularda yaşayan, vücudunda yirmi iki sindirim kesesi olduğu için bir kezde ağırlığının sekiz katı kan emebilen, halk arasında bazı kan hastalıklarının tedavisinde yararlanılan hayvan

sülük+çü Sülükle kan almayı meslek edinen kimse.

süs+lü Süsü olan, süslenmiş, bezenmiş

şahbaz Far. şah-bâz Çevik ve becerikli.

şaşı Birbirine paralel görme ekseni olmayan (göz veya kimse):

şilte+li+oğlu Ölen kişiden kalan giysi, yatak gibi şeyleri toplayan.

tabak Ar. debbağ Sepi işini yapan kimse, tabak.

tabla+cı Ar. tabla Mallarını tabla üzerinde satan kimse, tablakâr.

tamah Açgözlülük.

taslak Ar. tâs halk ağzında Görünüşü düzgün olmayan, kaba saba (insan ya da eşya için).

taşkala<telaş Ar. telâş Acelecilik.

taykeş (?)halk ağzında Birbirine uymayan, benzemeyen, tek kalan (ayakkabı, eldiven, öküz vb. çiftler için).

tazı Far. tâzî Genellikle tavşan avında kullanılan, uzun bacaklı, çekik karınlı, çok çevik bir tür köpek tekdaşşak<tek+daşşak Erkeklik hayaları tek olan.

tepirci halk ağzında İçinde hububatı savurarak yabancı maddelerden temizlemek için kullanılan kenarı kasnaklı, önü açık yarım daire şeklinde tahta tabla.

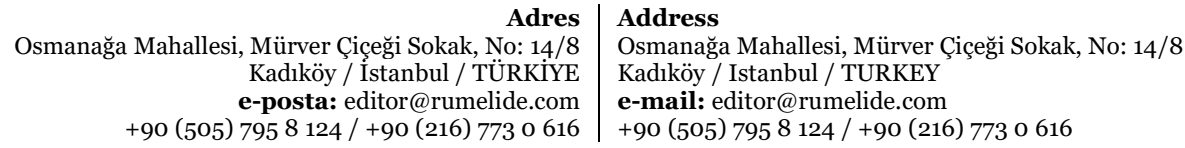


tilki halk ağzında Çok kurnaz.

tintin Sessiz, patırtısız.

topal Bacağındaki sakatlık sebebiyle seker gibi veya iki adımda bir, bir yana eğilerek yürüyen.

topal+fakıgil Ayağında sorun olan hoca.

topuz Ar. debbûs Ucu yumru biçiminde yuvarlak değnek vb. şeyler.

turfanda Far. tervende Mevsimin başında ilk yetişen (meyve, sebze).

tuluk halk ağzında Tulum.

tuvarlak<yuvarlak halk ağzında Top veya küre biçiminde toparlak.

uğur+lu Uğuru olan, iyilik getirdiğine inanılan, kutlu, tekin, kademli, meymenetli, mübarek.

Ukcursuz<uçkur Şalvarı bele bağlamak veya torba, kese vb. şeylerin ağzını büzmek için bunlara geçirilen bağ.

umar Bir şeyin olmasını bekleyen kimse.

ur+lu Hücrelerin aşırı çoğalmasıyla insan, hayvan veya bitki dokularında oluşan ve büyüme eğilimi gösteren yumru, bağa, tümör, neoplazma, Çingene ahtapotu, vejetasyon.

uyaran Uyarma işini yapan (kimse veya şey).

uysal Başkalarına kolayca uyabilen, sözlerini dinleyip karşı gelmeyen, yumuşak başlı.

uzun İki ucu arasında fazla uzaklık olan.

uzun+oğlu İki ucu arasında fazla uzaklık olan, maksi, kısa karşıtı.

ürkek korkuya çabuk kapılan.

vabis Alm. Bir marka.

vahşi Ar. Yabani

vakkas halk ağzında Kaz gibi "vak”layan.

vampir Fr. vampire İnsanların kanını emdiğine inanılan yaratık.

vapur Fr. vapeur Su buharı gücüyle çalışan gemi:

varak Ar. Yazılı kâğıt, varaka.

varil Fr. baril Halk ağzı. Silindir biçiminde olan kimse, çok yiyen.

varoş Mac.varos Kent veya kasabada kenar mahalle.

vasat Ar. Orta.

veci Ar. vech. Toz, biçim, yol.

vezir Ar. vezîr Kent veya kasabada kenar mahalle:

vukuf Ar. vukûf Anlama, bilme, bilgi.

vuslat Ar. Sevgiliye(Allah'a) kavuşma

yalak Hayvanların su içtikleri taş veya ağaçtan oyma kap.

yalan+cı Yalan söylemeyi huy edinmiş olan kimse.

yal+lı halk ağzında Obur, çok yiyen.

yamalık+lı Yama vurulmuş, yama ile onarılmış olan.

yangın halk ağzında Tutkun, düşkün, âşık.

yapı+cı Yapı yapan.

yavan halk ağzında Çirkin.

yıkım+cı Yapıları yıkma işini yapan kimse.

yobaz Dinde bağnazlığı aşırılığa vardıran, başkalarına baskı yapmaya yönelen (kimse).

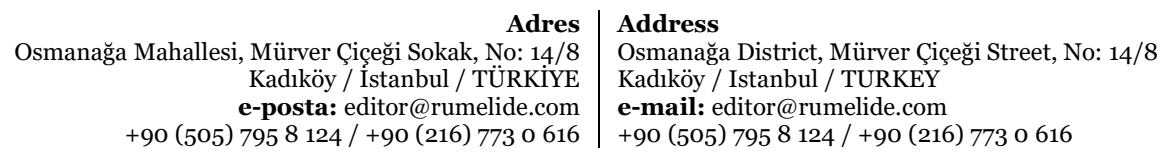


yosma halk ağzında Evli bir erkeğin ikinci eşine verilen ad.

yumuk halk ağzında Uysal, sessiz, içine kapanık.

yün+cü Koyun tüyüyle uğraşan kişi.

zalim Ar. zâlim Acımasız ve haksız davranan, zulmeden.

zambırlı halk ağzında Asabi, sinirli.

zambut (?)halk ağzında Soğanın kocamış tohumu.

zampara Far. zen+bâre Sürekli kadın peşinde koşan, kadınlara düşkün (erkek), kadıncıl, keskin, zendost.

zlbar Uyumak, çok içip sızmak. zilli Edepsiz, eli maşalı, şirret (kadın).

zukkum<zakkım Ar. zakkûm halk ağzında Zakkumgillerden, Akdeniz ülkelerinde yetișen, çiçekleri beyaz veya pembe renkli, kışın yapraklarını dökmeyen zehirli bir ağaççı, ağı ağacı, ağı çiçeği.

zula+cı Kaçak ve yasak şeylerin saklandığı gizli yer.

zurna+cı Far.surnây Zurna çalan kimse. 